\title{
Oxygen and indicators of stress for marine life in multi-model global warming projections
}

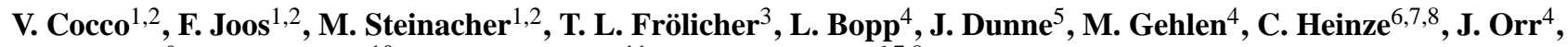 \\ A. Oschlies $^{9}$, B. Schneider ${ }^{10}$, J. Segschneider ${ }^{11}$, and J. Tjiputra ${ }^{6,7,8}$ \\ ${ }^{1}$ Climate and Environmental Physics, Physics Institute, University of Bern, Sidlerstrasse 5, 3012 Bern, Switzerland \\ ${ }^{2}$ Oeschger Centre for Climate Change Research, University of Bern, Zähringerstrasse 25, 3012 Bern, Switzerland \\ ${ }^{3}$ Atmospheric and Oceanic Sciences Program, Princeton University, Sayre Hall, Forrestal Campus, Princeton, NJ 08544, USA \\ ${ }^{4}$ Laboratoire des Sciences du Climat et de l'Environnement (LSCE), L'Orme des Merisiers Bât. 712 , 91191 Gif sur Yvette, \\ France \\ ${ }^{5}$ Geophysical Fluid Dynamics Laboratory, NOAA, Princeton, New Jersey 08540, USA \\ ${ }^{6}$ Geophysical Institute, University of Bergen, Allégaten 70, 5007 Bergen, Norway \\ ${ }^{7}$ Bjerknes Centre for Climate Research, Bergen, Norway, Allégaten 55, 5007 Bergen, Norway \\ ${ }^{8}$ Uni Klima, Uni Research, Allégaten 55, 5007 Bergen, Norway \\ ${ }^{9}$ Helmholtz Centre for Ocean Research Kiel (GEOMAR), Düsternbrooker Weg 20, 24105 Kiel, Germany \\ ${ }^{10}$ Institute of Geosciences, University of Kiel, Ludewig-Meyn-Str. 10, 24098 Kiel, Germany \\ ${ }^{11}$ Max-Planck-Institut für Meteorologie, Bundesstrasse 53, 20146 Hamburg, Germany \\ Correspondence to: V. Cocco (cocco@climate.unibe.ch)
}

Received: 18 July 2012 - Published in Biogeosciences Discuss.: 13 August 2012

Revised: 22 February 2013 - Accepted: 27 February 2013 - Published: 19 March 2013

\begin{abstract}
Decadal-to-century scale trends for a range of marine environmental variables in the upper mesopelagic layer (UML, 100-600 m) are investigated using results from seven Earth System Models forced by a high greenhouse gas emission scenario. The models as a class represent the observation-based distribution of oxygen $\left(\mathrm{O}_{2}\right)$ and carbon dioxide $\left(\mathrm{CO}_{2}\right)$, albeit major mismatches between observation-based and simulated values remain for individual models. By year 2100 all models project an increase in SST between $2{ }^{\circ} \mathrm{C}$ and $3{ }^{\circ} \mathrm{C}$, and a decrease in the $\mathrm{pH}$ and in the saturation state of water with respect to calcium carbonate minerals in the UML. A decrease in the total ocean inventory of dissolved oxygen by $2 \%$ to $4 \%$ is projected by the range of models. Projected $\mathrm{O}_{2}$ changes in the UML show a complex pattern with both increasing and decreasing trends reflecting the subtle balance of different competing factors such as circulation, production, remineralization, and temperature changes. Projected changes in the total volume of hypoxic and suboxic waters remain relatively small in all models. A widespread increase of $\mathrm{CO}_{2}$ in the UML is projected. The median of the $\mathrm{CO}_{2}$ distribution between
\end{abstract}

100 and $600 \mathrm{~m}$ shifts from $0.1-0.2 \mathrm{~mol} \mathrm{~m}^{-3}$ in year 1990 to $0.2-0.4 \mathrm{~mol} \mathrm{~m}^{-3}$ in year 2100 , primarily as a result of the invasion of anthropogenic carbon from the atmosphere. The co-occurrence of changes in a range of environmental variables indicates the need to further investigate their synergistic impacts on marine ecosystems and Earth System feedbacks.

\section{Introduction}

The ocean is undergoing physical and chemical changes in response to climate change caused by anthropogenic emissions of carbon dioxide $\left(\mathrm{CO}_{2}\right)$ and other greenhouse gases. These changes include widespread ocean warming, alterations in the stratification, density structure, circulation and physical transport rates, and an increase in total carbon content by air-sea $\mathrm{CO}_{2}$ uptake forcing the ocean towards more acidic conditions and altering acid-base relationships (Bindoff et al., 2007). Oxygen $\left(\mathrm{O}_{2}\right)$ and $\mathrm{CO}_{2}$ are involved in aerobic respiration where organic compounds and $\mathrm{O}_{2}$ are converted to $\mathrm{CO}_{2}$ and water. Global warming, 
expanding hypoxia and higher $\mathrm{CO}_{2}$ levels represent physiological stresses for marine aerobic organisms that may act synergistically with ocean acidification (Pörtner and Farrell, 2008).

The fugacity of carbon dioxide $\left(f \mathrm{CO}_{2}\right)$ and oxygen $\left(f \mathrm{O}_{2}\right)$ are two key thermodynamical variables for reporting the physiological state of aerobic marine animals (Hofmann et al., 2011; Seibel et al., 2012). The combined mechanisms of global $\mathrm{CO}_{2}$ (and $f \mathrm{CO}_{2}$ ) increase and more local deoxygenation (and $f \mathrm{O}_{2}$ decrease) have just begun to be addressed (e.g., Paulmier et al., 2011; Pörtner et al., 2011; Gruber, 2011; Mayol et al., 2012; Brewer and Peltzer, 2009) and need to be further investigated. Surprisingly, there is a lack of studies that project the combined evolution of these variables under global warming and anthropogenic carbon emissions using fully coupled Earth System Models.

The goals of this study are to provide multi-model estimates of decadal-to-century scale trends in $\mathrm{O}_{2}$ and $\mathrm{CO}_{2}$ (together with $f \mathrm{O}_{2}, f \mathrm{CO}_{2}$, and other biologically relevant variables), as well as to identify underlying mechanisms using global warming simulations from six fully coupled atmosphere-ocean general circulation models and one model of intermediate complexity. The analysis focuses on how anthropogenic carbon emissions and climate change affect decadal-to-century scale changes in $\mathrm{CO}_{2}$ and $\mathrm{O}_{2}$ within the upper mesopelagic layer (UML, from 100 to $600 \mathrm{~m}$ of depth) under the SRES A2 high-emission scenario. The performance of current Earth System Models in representing observation-based variables is assessed. Using the range of models, uncertainties in the projected changes in different environmental variables that are potentially relevant for marine life are explored. Thereby, the present analysis complements available studies on temperature, $\mathrm{pH}$ or calcium carbonate saturation state (i.e., the product of the concentrations of calcium ions and carbonate ion, divided by the apparent stoichiometric solubility product). Here we focus our analysis on the UML because within this layer $\mathrm{O}_{2}$ is depleted the most as a consequence of the $\mathrm{O}_{2}$ consumption associated with the remineralization of organic matter.

The concentrations of dissolved inorganic carbon (DIC, i.e., the sum of $\mathrm{CO}_{2}, \mathrm{HCO}_{3}^{-}$and $\mathrm{CO}_{3}^{2-}$ concentrations) as well as $f \mathrm{CO}_{2}$ are increasing in the surface ocean $(0-100 \mathrm{~m})$ and in the UML because a substantial fraction of the anthropogenic carbon emissions from fossil fuel burning and land use change is taken up by the ocean. Higher dissolved $\mathrm{CO}_{2}$ concentrations (i.e., the sum of $\mathrm{CO}_{2(\mathrm{aq})}$ and $\mathrm{H}_{2} \mathrm{CO}_{3}$ concentrations) induce, through acid-base equilibria, a decrease in $\mathrm{pH}$ and carbonate ion concentration, in turn reducing calcification in many calcareous organisms (Orr et al., 2005; Kroeker et al., 2010). Many physiological processes are sensitive to $\mathrm{CO}_{2}$ levels, and elevated $\mathrm{CO}_{2}$ concentrations may impose physiological stress on marine organisms more generally (Pörtner et al., 2008), even altering sensory responses and behavior of marine fishes (Nilsson et al., 2012). High $\mathrm{CO}_{2}$ may have detrimental effects on the survival, growth, and physiology of marine animals and impair oxygen transport by lowering blood pH (Pörtner et al., 2011).

Many observational (e.g., Pfeil et al., 2012; Watson et al., 2009; Lüger et al., 2006) and modeling (e.g., Keller et al., 2012; Tjiputra et al., 2012; Thomas et al., 2008) studies are directed towards understanding the air-sea $\mathrm{CO}_{2}$ fluxes and uptake of anthropogenic carbon by the ocean. Recently, observational studies focused on upwelling regions (Mayol et al., 2012; Paulmier et al., 2011), typical low- $\mathrm{O}_{2}-$ high- $\mathrm{CO}_{2}$ areas of particular vulnerability, where elevated $f \mathrm{CO}_{2}$ levels represent a key threat connecting aerobic stress and calcification challenges. However, $f \mathrm{CO}_{2}$ and $\mathrm{CO}_{2}$ are not state variables in ocean biogeochemical models and coupled Earth System Models, and their distribution below the surface layer has been studied poorly.

Observational studies indicate a mostly negative trend in the oxygen content over recent decades in different basins of the world's ocean (Stramma et al., 2008; Chan et al., 2008; Whitney et al., 2007; Mecking et al., 2006; Emerson et al., 2004; Joos et al., 2003; Keeling et al., 2010; Takatani et al., 2012). A recent global-scale observational study (Helm et al., 2011) supports the evidence of a widespread ocean $\mathrm{O}_{2}$ decrease between the 1970s and the 1990s. These authors, as well as Stramma et al. (2012), however, report also large areas where $\mathrm{O}_{2}$ has increased during recent decades.

The observed $\mathrm{O}_{2}$ variations are relatively small and trends can therefore be difficult to detect, although they can result in changes up to $50 \%$ in the low- $\mathrm{O}_{2}$ regions. There is no consensus in considering anthropogenic global warming as the main driver of the observed $\mathrm{O}_{2}$ changes because of the relatively short and sparse observational records. Natural variability may tend to mask the anthropogenically induced trends in dissolved $\mathrm{O}_{2}$, as suggested from both modeling (Frölicher et al., 2009) and observational (Mecking et al., 2008; Deutsch et al., 2011) studies.

Despite the uncertainties about the last-decade trends, a long-term decrease in the oceanic $\mathrm{O}_{2}$ inventory is expected under global warming and consistently simulated across a range of models (Sarmiento et al., 1998; Frölicher et al., 2009; Plattner et al., 2002; Bopp et al., 2002). Surface warming, lower sea surface $\mathrm{O}_{2}$ concentration, enhanced stratification, reduced ventilation of the thermocline, and slowed thermohaline circulation tend to decrease the resupply of $\mathrm{O}_{2}$ to the ocean interior, and to increase the residence time of water at depth, enhancing biological $\mathrm{O}_{2}$ utilization.

Higher $\mathrm{CO}_{2}$ levels may enhance $\mathrm{O}_{2}$ consumption at depth because of the higher $\mathrm{C} / \mathrm{N}$ ratio of the organic matter produced at high $\mathrm{CO}_{2}$ concentration, as shown in mesocosms experiments (Riebesell et al., 2007). As long as the $\mathrm{O}_{2} / \mathrm{C}$ ratio is not adjusted, this effect would lead to an expansion of the suboxic water volume in particular in the tropical oceans (Oschlies et al., 2008). On the other hand, reduced upwelling of nutrient-rich waters may decrease export of biologically produced organic carbon and the respiratory oxygen consumption in subsurface water. Many modeling studies identify 
circulation and mixing changes as main drivers of the ongoing and future $\mathrm{O}_{2}$ decline (Frölicher et al., 2009; Schmittner et al., 2008; Duteil and Oschlies, 2011; Bopp et al., 2002; Plattner et al., 2002). The observations reported by Helm et al. (2011) as well as earlier observation-based studies (e.g., Emerson et al., 2001) also support this explanation.

In the next section, simulations and experimental details are described. In the Appendix the model descriptions and additional plots are provided.

\section{Methods}

In this study we consider global warming simulations from seven Earth System Models including representations of terrestrial and marine biogeochemistry of different complexities. The models are forced with prescribed $\mathrm{CO}_{2}$ emissions from reconstructions (1870-2000 AD) and a high-emission scenario, SRES A2 (2000-2100 AD). The Earth System Models represent the interactions between the physical climate system, biogeochemical cycles, and marine ecosystems under global warming. Such interactions are included in global Earth System Models, but not in global ocean-only or high-resolution, eddy-resolving regional models. The strategy applied here is to analyze results from a broad suite of Earth System Models; the model spread in results provides a first indication of uncertainty.

The models are the IPSL-CM4-LOOP model from the Institut Pierre Simon Laplace (IPSL), the MPI-ESM Earth System Model from the Max Planck Institute for Meteorology (MPIM), two versions of the Community Climate System Model (CSM1.4-carbon and CCSM3-BEC) from the National Center for Atmospheric Research, the Bergen Climate Model (BCM-C) from the University of Bergen and Bjerknes Centre for Climate Research, the Earth System Model from the Geophysical Fluid Dynamics Laboratory in Princeton, and the UVIC2-8 as used by the Helmholtz Centre for Ocean Research Kiel (GEOMAR). These models are referred to as IPSL, MPIM, CSM1.4, CCSM3, BCM-C, GFDL and UVIC2-8, respectively.

UVIC2-8 is an Earth System Model of intermediate complexity in which the ocean component is coupled to a single-level model of the atmosphere and a dynamicthermodynamic sea ice component. The other models are fully coupled atmosphere-land-ocean carbon cycle general circulation models. The ocean model resolution ranges from about $1^{\circ} \times 1^{\circ}\left(\mathrm{GFDL}\right.$, up to $1 / 3^{\circ}$ near the equator) to about $3.6^{\circ} \times 1-2^{\circ}($ CCSM3, CSM1.4, and UVIC2-8). More details about the individual models are provided in Appendix A.

The same simulations with IPSL, MPIM, CCSM3 and CSM1.4 models considered in this study are analyzed in Steinacher et al. (2010) to investigate the ability of the models to represent the present spatio-temporal pattern of net primary production and to project its future changes under the high-emission scenario SRES A2. Further details about these four models and the experimental setup of the simulations considered here are provided in Steinacher et al. (2010). Schneider et al. (2008) present results for three (IPSL, MPIM, and CSM1.4) of the seven models used in this study. They provide detailed information on the performance of these three models under current climate conditions and compare modeled physical (temperature, salinity, mixed layer depth, meridional overturning, ENSO variability) and biological (primary and export production, chlorophyll concentration) results with observation-based estimates. Roy et al. (2011) investigate the impacts of climate change and rising $\mathrm{CO}_{2}$ on ocean carbon uptake with the simulations from IPSL, MPIM, CSM1.4 and BCM-C.

The models are forced by anthropogenic $\mathrm{CO}_{2}$ emissions from fossil fuel burning and land use changes as reconstructed for the industrial period (from 1870 to 1999 AD) and following the SRES A2 emission scenario after $2000 \mathrm{AD}$. The CSM1.4, CCSM3 and the MPIM model also partly include non-GHG forcings. Volcanic eruptions and changes in solar radiation over the historical period are also taken into account by CSM1.4 and CCSM3. The variables used in the analysis have been interpolated onto a common $1^{\circ} \times 1^{\circ}$ grid using a Gaussian weighted average of the data points within a radius of $4^{\circ}$ with a mapping scale of $2^{\circ}$. Control simulations in which atmospheric $\mathrm{CO}_{2}$ and other forcings are set to constant preindustrial levels are used to remove possible century scale model drifts for each grid point and for each month (Frölicher et al., 2009). This procedure is applied to the three-dimensional field of temperature, salinity, oxygen, DIC, alkalinity and nutrients used in the following analysis.

As a point of reference we use annual GLODAP (Key et al., 2004) and World Ocean Atlas 2009 (WOA 09) (Locarnini et al., 2010; Antonov et al., 2010; Garcia et al., 2010a,b) gridded data sets for data-model comparisons. The gridded data sets provide structured information, extremely valuable in model-data comparisons and to estimate global properties.

\section{$2.1 \mathrm{CO}_{2}, f \mathrm{CO}_{2}$ and $f \mathrm{O}_{2}$}

For this study, $\mathrm{CO}_{2}$ and $f \mathrm{CO}_{2}$ are computed using the standard OCMIP carbonate chemistry routines (Orr et al., 2005; Steinacher et al., 2009) as a function of DIC, temperature, alkalinity, salinity, phosphate, and silicate (from observed or modeled quantities). $f \mathrm{O}_{2}$ is computed following the Garcia and Gordon equation (Garcia and Gordon, 1992), in the version corrected by Sarmiento and Gruber (2006), as a function of dissolved $\mathrm{O}_{2}$, temperature and salinity (from observed or modeled fields). Changes in $f \mathrm{CO}_{2}$ are attributed to changes in individual variables, i.e., to changes in DIC, temperature, alkalinity or salinity. This is done by keeping all input variables except one at the 1870-1879 mean concentration in the carbonate chemistry computation. Similarly, changes in $f_{2}$ are attributed to changes in salinity, temperature, and $\mathrm{O}_{2}$. 
The mechanisms responsible for the 21st century $\mathrm{O}_{2}$ and DIC variations are investigated in more detail using CSM1.4 results and taking advantage of its relatively simple formulations for export production and remineralization. In CSM1.4 the stoichiometric $\mathrm{O}_{2}$ to $\mathrm{PO}_{4}$ ratio for production and remineralization is fixed at -170 . This allows splitting of the changes in $\mathrm{O}_{2}\left(\Delta \mathrm{O}_{2}\right)$ in individual components representing different drivers (see Frölicher et al., 2009). $\Delta \mathrm{O}_{2 \text { gas }}$ reflects the contribution by air-sea gas exchange on the $\mathrm{O}_{2}$ concentration; this component reflects the influence of warming on the solubility of $\mathrm{O}_{2} . \Delta \mathrm{O}_{2 \text { bio }}$ is computed by multiplying the change in phosphate concentration with the $\mathrm{O}_{2}$ to $\mathrm{PO}_{4}$ Redfield ratio; this reflects the influence from changes in the cycling of organic matter.

Similarly, the CSM1.4 changes in DIC due to marine production and remineralization of organic matter and calcite are linearly linked to variations in phosphate and alkalinity according to the fixed Redfield ratios (Plattner et al., 2001; Gruber and Sarmiento, 2002). This allows assignment of DIC changes $(\triangle D I C)$ to variations in the marine biological cycle $\left(\triangle \mathrm{DIC}_{\text {bio }}\right)$ and in air-sea gas exchange $\left(\triangle \mathrm{DIC}_{\mathrm{gas}}\right)$ (Frölicher and Joos, 2010). $\Delta$ DIC $_{\text {bio }}$ is given by the sum of two terms, representing the organic matter cycle and the calcium carbonate cycle contributions. The difference between $\triangle \mathrm{DIC}$ and $\triangle \mathrm{DIC}$ bio can be assigned to $\triangle \mathrm{DIC}_{\text {gas }}$.

\subsection{Respiration index}

Brewer and Peltzer (2009) proposed the "respiration index" (RI) as an indicator for estimating the physiological limits for deep-sea aerobic life. RI is a quantity linearly related to the available energy involved in the basic oxic respiration.

Generally, the limits to aerobic life in the ocean are defined in terms of a minimum dissolved $\mathrm{O}_{2}$ concentration, which is typically set to $5 \mathrm{mmolm}^{-3}$. Below this concentration microbes turn to other electron acceptors as it becomes inefficient to consume $\mathrm{O}_{2}$. However, by defining the limit in terms of oxygen only, the potential influence of $\mathrm{CO}_{2}$ on respiration is neglected. Brewer and Peltzer (2009), considering the basic oxic respiration equation $\mathrm{C}_{\mathrm{org}}+\mathrm{O}_{2} \rightarrow \mathrm{CO}_{2}$ and the related Gibbs free energy (proportional to $\log _{10}\left(f \mathrm{O}_{2} / f \mathrm{CO}_{2}\right)$ ), proposed the RI.

Brewer and Peltzer (2009) proposed the RI with the following thresholds, which can be used to map changing conditions: $\mathrm{RI} \leq 0$ corresponds to the thermodynamic aerobic limit (formal dead zone); the range $0 \leq \mathrm{RI} \leq 0.4$ has been proposed as "practical dead zone"; RI between 0.4 and 0.7 represents the practical limit of aerobic respiration; the interval from 0.7 to 1 may define an aerobic stress regime. The actual limits will be, however, strongly species dependent and still need to be experimentally validated, as noted by Brewer and Peltzer.

Criticisms of the concept were raised and its practical usefulness has been questioned (Seibel et al., 2012; Pörtner et al., 2011). The mechanisms of transport of $\mathrm{O}_{2}$ and $\mathrm{CO}_{2}$ between the environment and tissues are important controls influencing aerobic performance of large animals; a factor not included in the definition of RI. Acknowledging this limitation, we project changes in RI as another possible indicator of aerobic stress.

\section{Results}

\subsection{Model evaluation}

We start comparing model results with observation-based estimates of the present-day annual mean distributions of $f \mathrm{O}_{2}$, $\mathrm{O}_{2}, f \mathrm{CO}_{2}$, DIC, and RI. First, the skill of the different models in representing the observation-based fields for the world ocean between 100 and $600 \mathrm{~m}$ of depth is assessed by Taylor diagrams (Taylor, 2001) (Fig. 1). The Taylor diagrams allow us to visualize the correspondence between model results and observation-based variables. The polar coordinates represent the correlation coefficient $R$ (polar angle) and the normalized standard deviation $\sigma_{\text {model }} / \sigma_{\text {obs }}$ (radius). In such a diagram the points corresponding to the observation-based variables would lie all at $\left(R=1, \sigma_{\text {model }} / \sigma_{\mathrm{obs}}=1\right)$. The Taylor diagrams of temperature, salinity, phosphate and mixed layer depth can be found in Roy et al. (2011) for the MPIM, IPSL, BCM-C, and CSM1.4 models. $\mathrm{O}_{2}$ mean value and standard deviation $(\sigma)$ for WOA 09 and the models are listed in the table in Fig. 1a. BCM-C oxygen mean value and $\sigma$ match the observations, GFDL has a slightly low mean value and the other models present in general too high mean values and too low $\sigma$. The correlation coefficient $(R)$ for $\mathrm{O}_{2}$ and $f \mathrm{O}_{2}$ ranges for all models between 0.7 and 0.9 , with a normalized standard deviation $\left(\sigma_{\text {model }} / \sigma_{\text {obs }}\right)$ between 0.7 and 1.1 for both variables (Fig. 1). DIC shows very similar $R$ values, and slightly higher normalized standard deviations (between 0.8 and 1.25).

The results for $f \mathrm{CO}_{2}$ and $\mathrm{RI}$ are less satisfying. The correlation with the observation-based fields is lower than 0.6 for CCSM3 and CSM1.4 (for both variables) and for BCM$\mathrm{C}$ (for $f \mathrm{CO}_{2}$ ). The normalized standard deviation for $f \mathrm{CO}_{2}$ lies between 1.1 (MPIM) and 1.9 (BCM-C), while for RI it ranges from 0.9 (IPSL) to 2.75 (CSM1.4 and CCSM3). The simplest model, UVIC2-8, produces the highest $R$ values for all variables and normalized standard deviations between 0.9 and 1.2 for $\mathrm{O}_{2}, f \mathrm{O}_{2}$, DIC and RI. These results are in good agreement with the observation-based annual mean fields, compared with other models. This is true for the annual mean distribution; however, the situation for UVIC2-8 would look considerably worse considering the seasonal cycle.

Next, we compare the simulated and observation-based frequency distributions for $\mathrm{O}_{2}$ and $\mathrm{CO}_{2}$ within the UML. The frequency distributions allow us to assess whether the models are able to represent the volume associated with a given concentration interval. Unlike the information in a Taylor diagram, the frequency distribution does not depend on the 

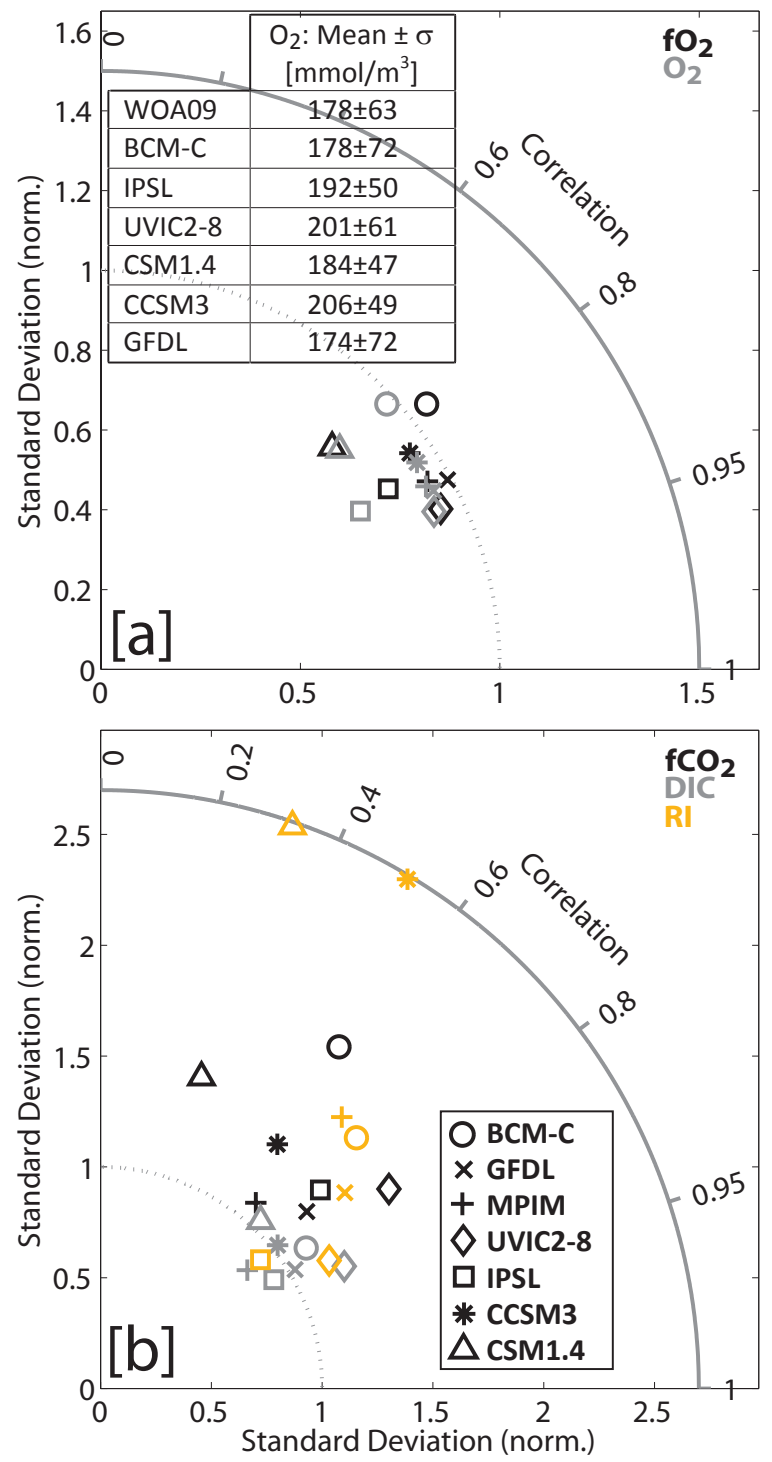

Fig. 1. Taylor diagrams: correspondence between model results (1990-1999 average) and observation-based (from GLODAP and WOA 09, annual mean) $f \mathrm{O}_{2}$ and $\mathrm{O}_{2}$ (a), $f \mathrm{CO}_{2}$, RI, and DIC (b). The polar coordinates represent the correlation coefficient $R$ (polar angle) and the normalized standard deviation $\sigma_{\text {model }} / \sigma_{\text {obs }}$ (radius). The results are relative to data between 100 and $600 \mathrm{~m}$ depth and are weighted by the volume of each grid cell. Observed and modeled $\mathrm{O}_{2}$ mean values and standard deviations $(\sigma)$ relative to the results of (a) are summarized in the table included in (a).

geographical location and is as such insensitive to a geographical mismatch between observed and modeled water masses. Modeled and observation-based $\mathrm{O}_{2}$ and $\mathrm{CO}_{2}$ frequency distributions are shown in Figs. 2 and 3. Similarly to the observation-based $\mathrm{O}_{2}$ frequency distribution, the modeled $\mathrm{O}_{2}$ frequencies range between 0 and $400 \mathrm{mmol} \mathrm{m}^{-3}$, indicating the ability of the models to reproduce the correct range of variability of $\mathrm{O}_{2}$ in the UML. The highest peak in

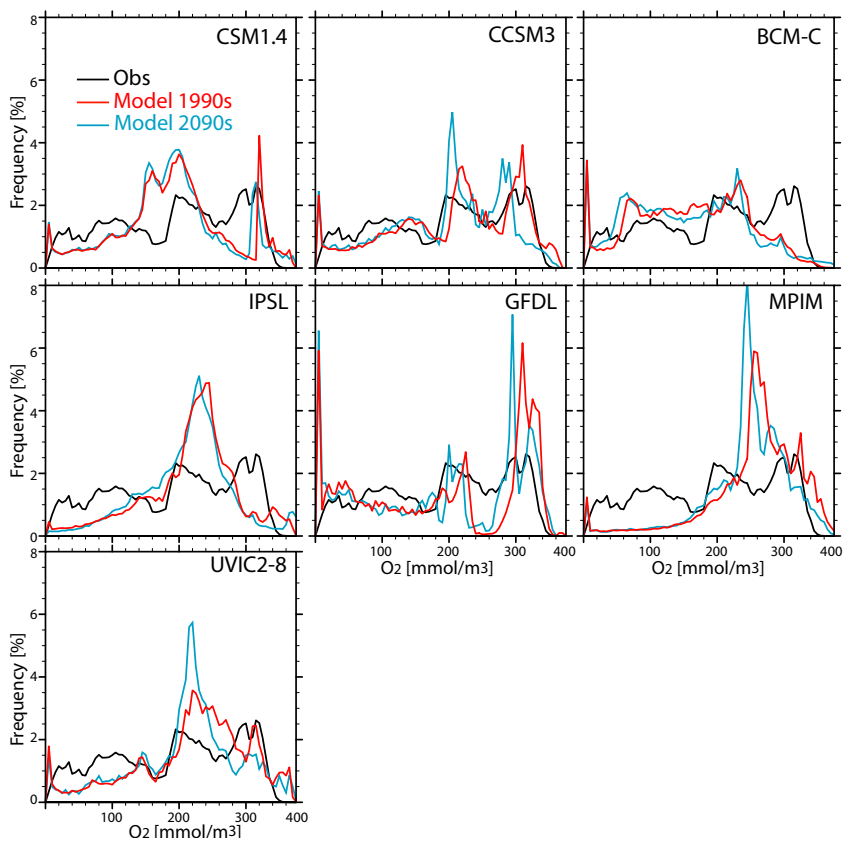

Fig. 2. $\mathrm{O}_{2}$ frequency distribution in the UML (from 100 to $600 \mathrm{~m}$ depth), obtained by sampling the volume fraction that falls within $20 \mathrm{mmol} \mathrm{m}^{-3}$ intervals. Black line: observation-based distribution (from GLODAP and WOA 09 gridded data). Red: 1990s modeled distribution (decadal mean). Blue: 2090s modeled distribution (decadal mean).

the observations is at $\sim 300 \mathrm{mmolm}^{-3}$. Most models tend to overestimate the magnitude of this peak and/or exhibit it between 200 and $240 \mathrm{mmol} \mathrm{m}^{-3}$.

The observation-based and modeled $\mathrm{CO}_{2}$ values lie mostly between 0.01 and $0.06 \mathrm{molm}^{-3}$, with the highest peak at $\sim$ $0.02 \mathrm{~mol} \mathrm{~m}^{-3}$ (Fig. 3). The magnitude of this peak is largely overestimated by CSM1.4, MPIM and, to a smaller extent, CCSM3 and GFDL. Modeled and observation-based volumes related to three $\mathrm{O}_{2}$ concentration intervals in the low$\mathrm{O}_{2}$ range (Table 1) are analyzed next. For $\mathrm{O}_{2}<80 \mathrm{mmolm}^{-3}$ IPSL, UVIC2-8, CSM1.4, and CCSM3 underestimate the associated volume by a factor between 1.8 (UVIC2-8) and 3 (CSM1.4), compared to the data-based estimates. The other models overestimate it slightly (by a factor of 1.3 for the MPIM and 1.1 for the BCM-C). In the hypoxic range $\left(\mathrm{O}_{2}<50 \mathrm{mmol} \mathrm{m}^{-3}\right)$ the situation is analogous.

On the other hand, all models overestimate the water volume in the suboxic regime $\left(\mathrm{O}_{2}<5 \mathrm{mmolm}^{-3}\right)$. The IPSL results are close to WOA $09 \mathrm{O}_{2}$ (respectively, $0.08 \%$ and $0.05 \%$ of the total volume of each data set). The other models simulate large discrepancies from the observations, in particular GFDL and MPIM. As pointed out by Bianchi et al. (2012), these discrepancies in the suboxic regions could be only partially attributed to deficiencies of the gridded WOA $\mathrm{O}_{2}$ data set in representing the $\mathrm{O}_{2}$ minimum zones (OMZs), whose extent is considered by 
Table 1. Observed and modeled present-day and 2090s (decadal average) volume of three water classes identified by different $\mathrm{O}_{2}$ regimes, expressed in $\mathrm{m}^{3}$ and in percent of the total oceanic volume. In the first line, the revised WOA 05 values from Bianchi et al. (2012) are listed.

\begin{tabular}{|c|c|c|c|c|c|c|}
\hline & \multicolumn{6}{|c|}{ Volume $\left[10^{15} \mathrm{~m}^{3}\right]$ (\% of the total) } \\
\hline & \multicolumn{3}{|c|}{$1990 \mathrm{~s}$} & \multicolumn{3}{|c|}{$2090 \mathrm{~s}$} \\
\hline & $\begin{array}{c}\mathrm{O}_{2}<80 \\
\mathrm{mmolm}^{-3}\end{array}$ & $\begin{array}{c}\mathrm{O}_{2}<50 \\
\mathrm{mmolm}^{-3}\end{array}$ & $\begin{array}{c}\mathrm{O}_{2}<5 \\
\mathrm{mmolm}^{-3}\end{array}$ & $\begin{array}{c}\mathrm{O}_{2}<80 \\
\mathrm{mmolm}^{-3}\end{array}$ & $\begin{array}{c}\mathrm{O}_{2}<50 \\
\mathrm{mmolm}^{-3}\end{array}$ & $\begin{array}{c}\mathrm{O}_{2}<5 \\
\mathrm{mmolm}^{-3}\end{array}$ \\
\hline Bianchi et al. & $126(8.58)$ & $60.4(4.33)$ & $2.43(0.16)$ & - & - & - \\
\hline WOA 09 & $121(8.27)$ & $60.0(4.10)$ & $0.76(0.05)$ & - & - & - \\
\hline BCM-C & $137(10.4)$ & $68.4(5.20)$ & $19.9(1.51)$ & 139 (10.6) & $67.3(5.12)$ & $19.5(1.48)$ \\
\hline IPSL & $38.9(2.98)$ & $18.5(1.42)$ & $1.01(0.08)$ & $43.8(3.36)$ & $17.7(1.36)$ & $0.93(0.07)$ \\
\hline UVIC2-8 & $67.9(5.01)$ & $32.9(2.43)$ & $4.91(0.36)$ & $67.8(4.99)$ & $32.8(2.42)$ & $4.91(0.36)$ \\
\hline CSM1.4 & $33.3(2.55)$ & $18.1(1.38)$ & $5.44(0.42)$ & $35.8(2.74)$ & $18.7(1.43)$ & $5.39(0.41)$ \\
\hline CCSM3 & $38.6(2.94)$ & $22.5(1.71)$ & $6.55(0.50)$ & $40.4(3.07)$ & $23.3(1.77)$ & $6.36(0.48)$ \\
\hline GFDL & $153(10.7)$ & $105(7.35)$ & $39.9(2.79)$ & $152(10.6)$ & $104(7.28)$ & $39.6(2.77)$ \\
\hline MPIM & $154(11.3)$ & $93.6(6.87)$ & $35.7(2.26)$ & $152(11.1)$ & $92.4(6.78)$ & $32.9(2.42)$ \\
\hline
\end{tabular}

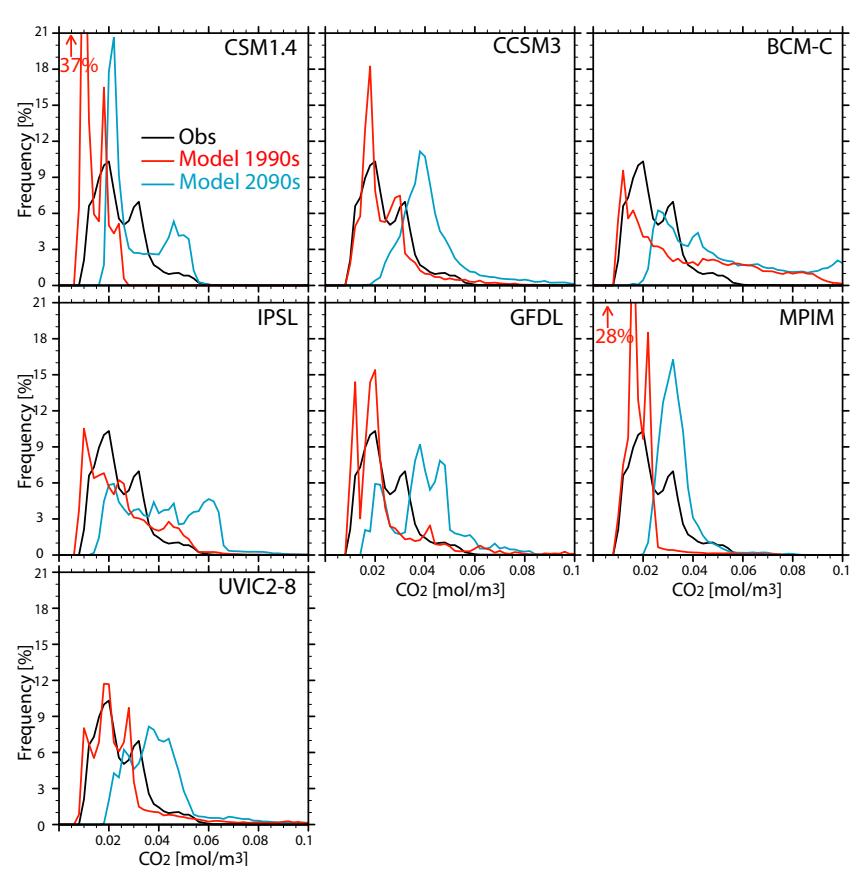

Fig. 3. $\mathrm{CO}_{2}$ frequency distribution in the UML (from 100 to $600 \mathrm{~m}$ depth), obtained by sampling the volume fraction that falls within $0.02 \mathrm{~mol} \mathrm{~m}^{-3}$ intervals. Black line: observation-based distribution (from GLODAP and WOA 09 gridded data). Red: 1990s modeled distribution (decadal mean). Blue: 2090s modeled distribution (decadal mean).

Bianchi et al. (2012) to be underestimated by a factor of three in the WOA 09 gridded data set. The spatial distributions of $\mathrm{O}_{2}$ and $\mathrm{CO}_{2}$ in the UML are compared with observations using averaged values over the $100-600 \mathrm{~m}$ depth range (Figs. B1 and B2 in Appendix B). The $\mathrm{CO}_{2}$ pattern mirrors the $\mathrm{O}_{2}$ distribution in observations and model results. This reflects the connection between the two variables via remineralization-production. High $\mathrm{O}_{2}$ values are associated with low $\mathrm{CO}_{2}$ values and vice versa. The observation-based $\mathrm{O}_{2}\left(\mathrm{CO}_{2}\right)$ distribution exhibits generally high (low) values in the mid-latitude regions of both hemispheres and low (high) values in the tropics. Lowest $\mathrm{O}_{2}$ and highest $\mathrm{CO}_{2}$ values are observed in the Arabian Sea, the Bay of Bengal and the eastern boundary upwelling systems of the Pacific and South Atlantic.

The models underestimate $\mathrm{O}_{2}$ and overestimate $\mathrm{CO}_{2}$ in the Atlantic eastern boundary upwelling regions, and, to some extent, in the Bay of Bengal, while they tend to overestimate $\mathrm{O}_{2}$ and underestimate $\mathrm{CO}_{2}$ in the Arabian Sea and in large areas of the Pacific - in particular in the North Pacific. These mismatches are linked to too low export production in the North Pacific and the Arabian Sea and too high export in the Bay of Bengal in the models (Steinacher et al., 2010). The relatively pronounced $\mathrm{O}_{2}$ and $\mathrm{CO}_{2}$ biases simulated by BCM-C in the Southern Ocean are related to the strong mixing process. Despite these deficiencies, the models represent many features of the observation-based $\mathrm{CO}_{2}$ and $\mathrm{O}_{2}$ fields between 100 and 600 meter depth, such as low $\mathrm{O}_{2}$ in the equatorial and eastern boundary upwelling systems, high $\mathrm{O}_{2}$ in the gyres and in the North Atlantic, and lower $\mathrm{O}_{2}$ in the North Pacific (Fig. B1 in Appendix B). Other reproduced features are the low $\mathrm{CO}_{2}$ in the gyres and higher values in the equatorial and eastern boundary upwelling regions (Fig. B2 in Appendix B).

In conclusion, the comparison between model results and data-based estimates reveals that, while representing major large-scale features and global trends, the models suffer from considerable shortcomings in the representation of $\mathrm{O}_{2}$ and $\mathrm{CO}_{2}$. Regionally, large deviations in the $\mathrm{CO}_{2}$ in the UML compared to observations are not a surprise. Deviations in modeled DIC, alkalinity, temperature, and salinity all contribute to deviations in $\mathrm{CO}_{2}$ and resulting errors can be large even if deviations in the four state variables (DIC, ALK, TEMP, and SALT) are modest as the carbonate chemistry is non-linear. In any case, the top-down forcing by rising 
atmospheric $\mathrm{CO}_{2}$ concentrations leads to rising DIC concentrations (and $f \mathrm{CO}_{2}$ ), as found in the models and in observations. Perhaps more problematic is the misrepresentation of the $\mathrm{O}_{2}$ fields in the tropical UML. As the interest is to a large extent on the future evolution of low-oxygen regions, the challenge is in the correct representation of subtle changes in the balance between $\mathrm{O}_{2}$ supply to the thermocline by physical mixing and advection, and $\mathrm{O}_{2}$ consumption by remineralization of organic material. Thus, we expect that projections of the evolution of low $\mathrm{O}_{2}$ regions will vary among the models and be affected by large uncertainties.

\subsection{Projections}

Figure 4 presents an overview of the current and projected distribution in the UML for a set of variables of potential biological relevance: temperature, $\mathrm{O}_{2}, \mathrm{CO}_{2}, \mathrm{RI}, \mathrm{pH}$, and saturation state of water with respect to aragonite $\left(\Omega_{\mathrm{A}}\right)$. A widespread warming of the UML is projected under the SRES A2 scenario with typical temperature changes over the 21 st century of 1 to $2{ }^{\circ} \mathrm{C}$. The 21 st century changes in $\mathrm{O}_{2}$ are less conspicuous on a global scale and no large expansion or contraction of thermocline regions with low $\mathrm{O}_{2}$ is projected (variations are in general around $\pm 10 \mathrm{mmolm}^{-3}$ ). On the other hand, a large increase in $\mathrm{CO}_{2}$ is projected everywhere in the UML. Concomitantly, a decrease in RI, pH, and $\Omega_{\mathrm{A}}$ is evident in Fig. 4. The different models simulate a consistent increase in sea surface temperature, $\mathrm{CO}_{2}$ uptake and $\mathrm{O}_{2}$ outgassing (Fig. 5). Therefore, a widespread change in physical and chemical ocean properties is projected. Changes in $\mathrm{O}_{2}, \mathrm{CO}_{2}, f \mathrm{O}_{2}, f \mathrm{CO}_{2}$, and $\mathrm{RI}$ for the individual models are analyzed in more detail in the following sections.

\subsubsection{Oxygen and $f \mathrm{O}_{2}$}

A global decline in the oceanic dissolved oxygen inventory is projected by all models, with a 1870-2100 decrease between $2 \%$ and $4 \%$ (for details about CSM1.4 see Frölicher et al., 2009). The 21 st century changes in the frequency distribution of $\mathrm{O}_{2}$ in the UML are modest (Fig. 2), with higher values becoming somewhat less abundant (in particular for MPIM, GFDL,UVIC2-8, and CCSM3). $\mathrm{O}_{2}$ changes in the UML (Fig. 6) show a complex pattern that reflects the influence of different competing factors such as circulation, production, remineralization and temperature changes. The models simulate consistently, i.e., at least five of the seven models agree in sign, a decrease in $\mathrm{O}_{2}$ in the UML of the northern Pacific, the tropical and subtropical South Pacific, the Southern Ocean, the eastern part of the Indian Ocean and the subpolar North Atlantic. A relatively small increase in $\mathrm{O}_{2}$ is consistently found in the multi-model average in the UML of the tropical oceans - including the eastern boundary upwelling system, the Caribbean Sea, western parts of the Indian Ocean, and the California upwelling region. The decrease is particularly pronounced (up to $-60 \mathrm{mmolm}^{-3}$ )

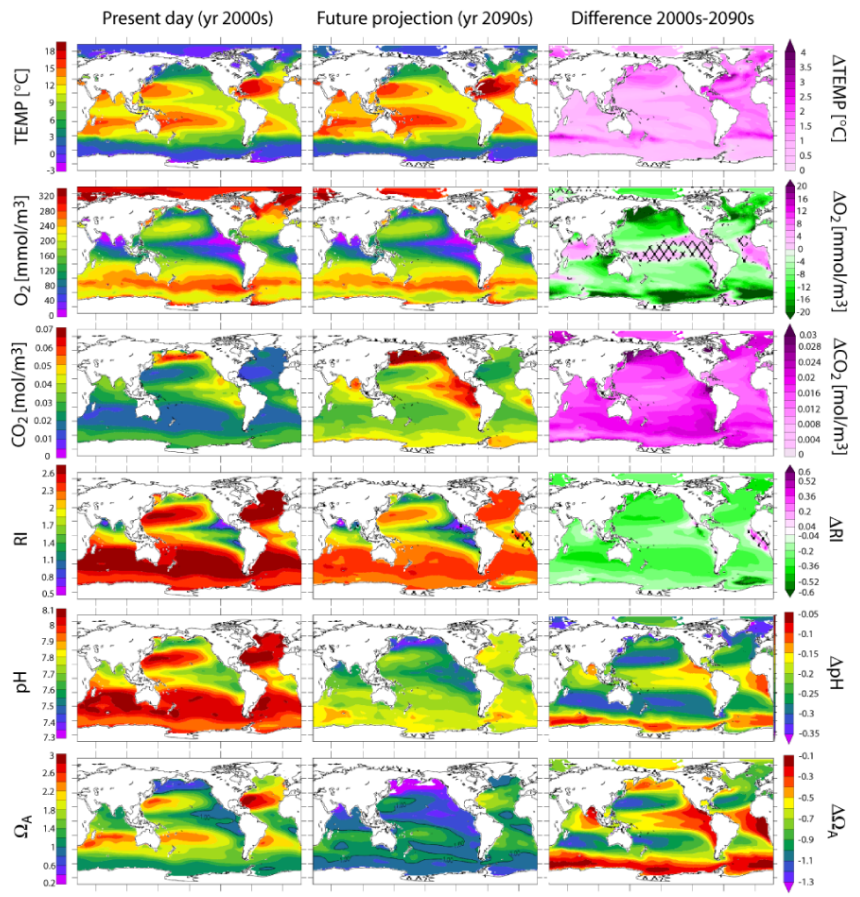

Fig. 4. Current and projected temperature, $\mathrm{O}_{2}, \mathrm{CO}_{2}, \mathrm{RI}, \mathrm{pH}$, and $\Omega_{\mathrm{A}}$ (100-600 $\mathrm{m}$ depth average). Observation-based fields from GLODAP and WOA 09 are shown on the left. The second column shows the projected 2090s distributions under the SRES A2 scenario, calculated as the sum of the observation-based fields and the 1990-2100 multi-model mean changes. The panels on the right represent the differences between the second and the first column. Hatched areas indicate where less than five out of seven models agree in the sign of the projected change. The contours represent the thresholds $\mathrm{RI}=1$ and $\Omega_{\mathrm{A}}=1$.

in the northwestern Pacific in UVIC2-8, BCM-C, IPSL and GFDL. Modest changes are found in the UML around $40^{\circ} \mathrm{S}$, north of the equatorial Pacific, and in the subtropical Atlantic.

We next turn our attention to the low- $\mathrm{O}_{2}$ regions and analyze whether they are projected to expand or to contract until 2100 under the SRES A2 forcing. Specifically, we address changes in the volume occupied with waters that hold less than $80 \mathrm{mmolm}^{-3}$, less than $50 \mathrm{mmolm}^{-3}$, and less than $5 \mathrm{mmolm}^{-3}$ (Table 1 and Fig. 7). In Table 1 the projected 2090s (2090-2099 average) volume for the three low- $\mathrm{O}_{2}$ regimes and the different models is listed. While most models project a contraction of the suboxic waters $\left(\mathrm{O}_{2}<5 \mathrm{mmolm}^{-3}\right)$, the model projections are not in agreement about the more oxygenated waters. Figure 7 illustrates the temporal evolution of the water volumes with low- $\mathrm{O}_{2}$, corresponding relatively to the 1870 s (1870-1879 average) volume for each model and each low- $\mathrm{O}_{2}$ class. By year 2100 , four models project a modest expansion of the regions with $\mathrm{O}_{2}$ concentration below $80 \mathrm{mmolm}^{-3}$ (Fig. 7a), in the range between $2 \%$ (BCM-C) and $16 \%$ (IPSL). UVIC2-8 does not 


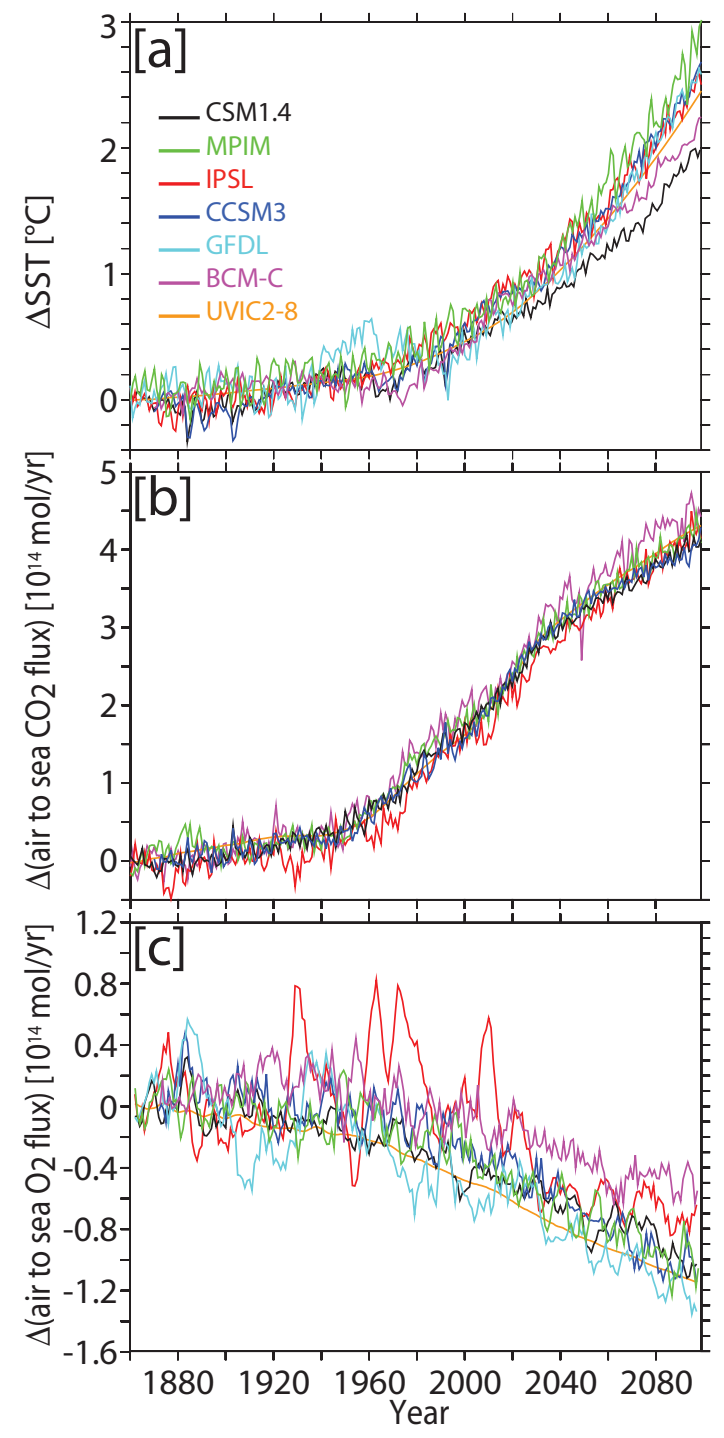

Fig. 5. Changes in sea surface temperature (a), air-sea $\mathrm{CO}_{2}$ flux (b) and air-sea $\mathrm{O}_{2}$ flux (c) for the global ocean over the period 1860-2100.

exhibit relevant changes, and GFDL and MPIM show, respectively, a $2 \%$ and $26 \%$ reduction.

Projected changes in the volume with $\mathrm{O}_{2}$ concentrations below $50 \mathrm{mmol} \mathrm{m}^{-3}$ (Fig. 7b) are smaller: two models (CCSM3, CSM1.4) project a $4.5 \%$ volume increase, while the others project a decrease between $0.4 \%$ (UVIC2-8) and $4.5 \%$ (MPIM). For suboxic conditions $\left(\mathrm{O}_{2}\right.$ concentration below $5 \mathrm{mmolm}^{-3}$, Fig. 7c), the volume is projected by most models to contract slightly (up to $-10 \%$ ). However, IPSL projects a $25 \%$ contraction of the suboxic volume in the 2090 s with respect to the condition in the 1870s.

Internal variability may mask part of the model-model differences, since we are analyzing single-mode simulations. Some models feature large interannual and decadal-scale variability in the volume evolution (especially IPSL). If such

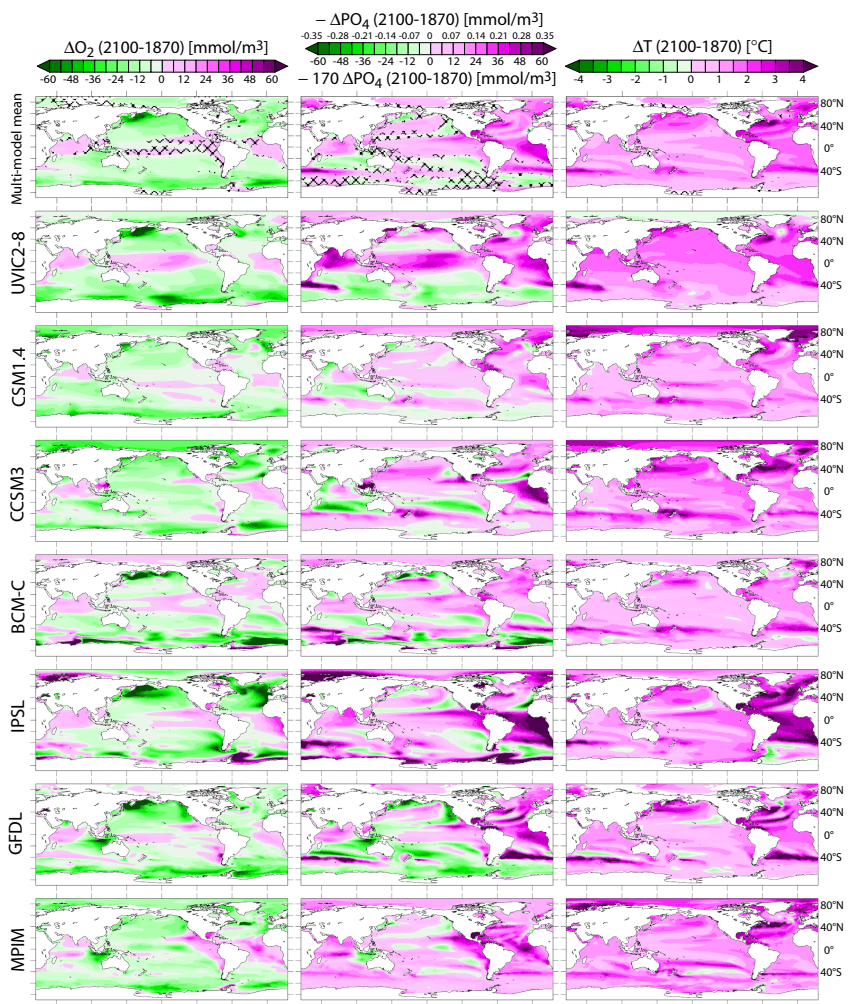

Fig. 6. Projected changes in $f \mathrm{O}_{2}$ in the UML (100 to $600 \mathrm{~m}$ depth) for the SRES A2 scenario. Changes are for 2100 relative to 1870. The multi-model mean is given in the upper left panel; hatched areas indicate where less than five out of seven models agree in the sign of the projected change.

a high variability is real, then it remains difficult to attribute current observation-based trends in low- $\mathrm{O}_{2}$ regions to external natural or anthropogenic forcings. Conversely, UVIC28 does not show much variability, as it is an Earth System Model of intermediate complexity in which the ocean component is coupled to a single-level model of the atmosphere.

As a representative example, we quantify for CSM1.4 the individual contribution of changes in salinity, temperature and $\mathrm{O}_{2}$ to the change in the globally averaged depth profile of $f \mathrm{O}_{2}$ from 1870 to 2100 and for the SRES A2 scenario (Fig. 8a). Similar results are found for different ocean basins and the other models. $f \mathrm{O}_{2}$ decreases on global average on all subsurface layers by 10 to 25 matm. The largest decrease is found at around $250 \mathrm{~m}$. At the surface $f \mathrm{O}_{2}$ increases by 7 matm on global average. The $\mathrm{O}_{2}$ concentration decreases in all depth layers on the global average. This decrease is the dominant driver of the decrease in $f \mathrm{O}_{2}$ in the UML and the deep ocean. The influence of changes in $\mathrm{O}_{2}$ concentration is completely offset at the surface and, to some extent, in the thermocline by changes in temperature, while in the deep ocean the influence of temperature changes on $f \mathrm{O}_{2}$ changes remains small. Changes in salinity generally have a small impact. 


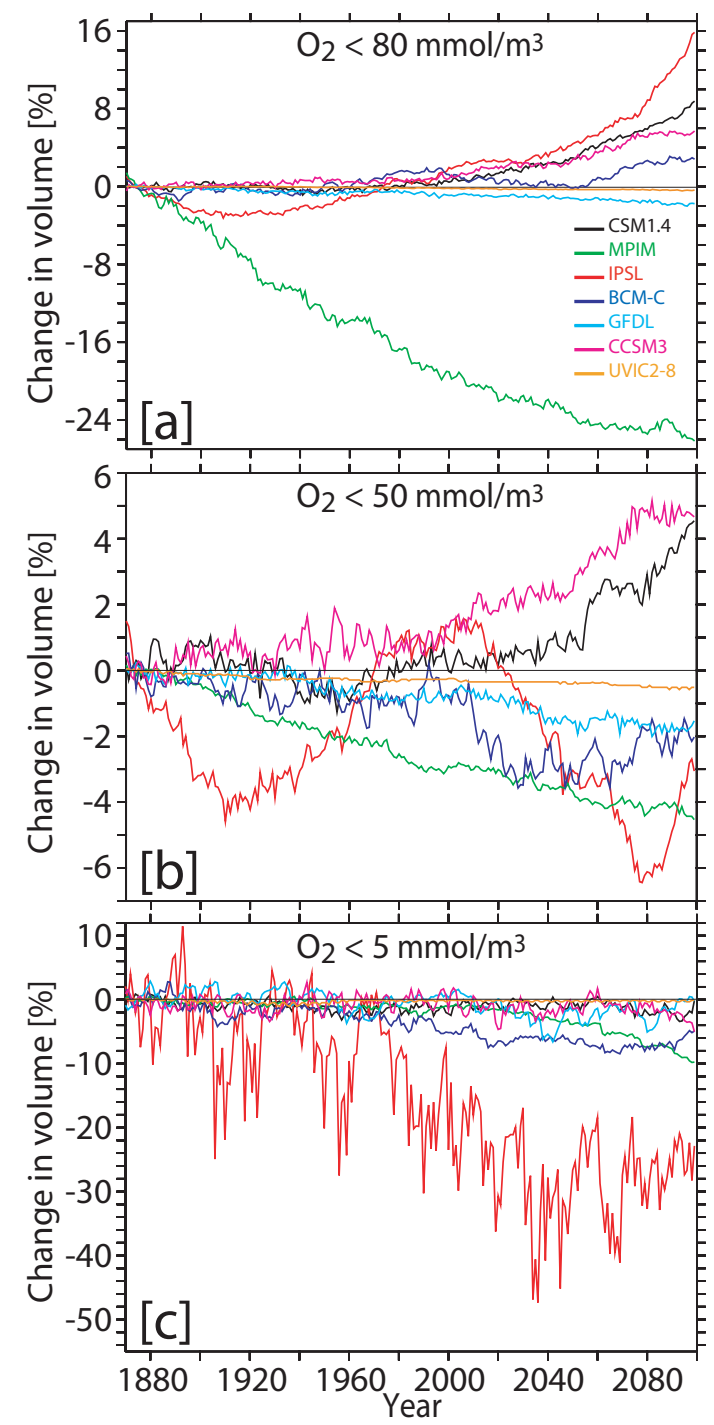

Fig. 7. Projected evolution of the global ocean volume occupied by (a) low-oxygenated waters $\left(\mathrm{O}_{2}<80 \mathrm{mmolm}^{-3}\right)$, (b) hypoxic waters $\left(\mathrm{O}_{2}<50 \mathrm{mmolm}^{-3}\right)$ and (c) suboxic waters $\left(\mathrm{O}_{2}<5 \mathrm{mmolm}^{-3}\right)$ for the SRES A2 scenario and the range of models. Changes are given in percent of the 1870 s volume, relative to each low- $\mathrm{O}_{2}$ class and each model.

Next, we quantify the different mechanisms responsible for the changes in the $\mathrm{O}_{2}$ concentration following the procedure described in the experimental design section and adopted from Frölicher et al. (2009). Rising temperatures affect $\mathrm{O}_{2}$ concentrations directly through the temperature dependence of gas solubility - estimated in previous studies being responsible for $25 \%$ to $50 \%$ of the total $\mathrm{O}_{2}$ changes (Bopp et al., 2002; Plattner et al., 2002; Frölicher et al., 2009). But warming induces also indirect effects, via stratification, circulation and soft-tissue pump alterations. As an illustration, we discuss average $\mathrm{O}_{2}$ changes in the UML of the entire Atlantic Basin and in the Atlantic OMZs (i.e., $\mathrm{O}_{2}$
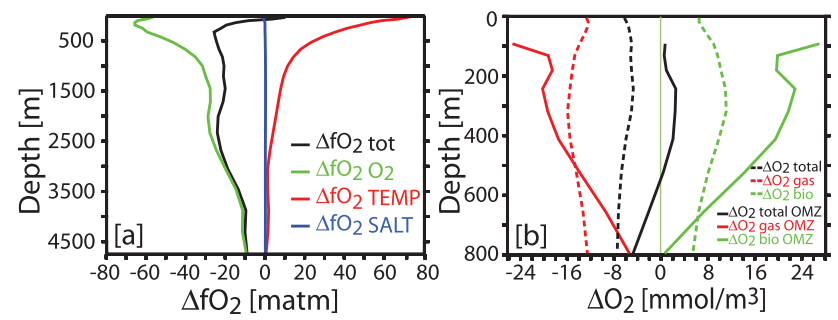

Fig. 8. Attribution to different drivers for changes (a) in $f \mathrm{O}_{2}$ for the global ocean and (b) in dissolved $\mathrm{O}_{2}$ for the entire Atlantic (dashed lines) and for Atlantic hypoxic waters $\left(\mathrm{O}_{2}<50 \mathrm{mmolm}^{-3}\right.$, solid lines). Results are from CSM1.4 and represent differences between 1870 s and 2090s. Colors in panel (a) indicate total changes in $f \mathrm{O}_{2}$ (black), $f \mathrm{O}_{2}$ changes due to changes in dissolved $\mathrm{O}_{2}$ (green), in temperature (red), and in salinity (blue). Colors in panel (b) indicate total $\mathrm{O}_{2}$ changes $\left(\Delta \mathrm{O}_{2}\right.$, black line $)$, changes due to the air-sea $\mathrm{O}_{2}$ disequilibrium $\left(\Delta \mathrm{O}_{2 \mathrm{gas}}\right.$, red), and to alterations in the cycling of organic matter $\left(\Delta \mathrm{O}_{2 \text { bio }}\right.$, green $)$.

smaller than $50 \mathrm{mmolm}^{-3}$ ) as simulated by CSM1.4 over the period from 1870 to 2100 (Fig. 8b). The focus is on the Atlantic Basin because CSM1.4, compared to other models, simulates OMZs of limited extension in the Pacific.

In the Atlantic as a whole, $\mathrm{O}_{2}$ concentrations decrease on average by around $7 \mathrm{mmolm}^{-3}$ in the upper $800 \mathrm{~m}$. This decrease is driven by $\left(\Delta \mathrm{O}_{2 \mathrm{gas}}\right)$, i.e., by changes in solubility and air-sea fluxes not directly associated with changes in saturation concentration, whereas the reorganization of the biological cycle leads to a decrease in phosphate and a related increase in $\mathrm{O}_{2}\left(\Delta \mathrm{O}_{2 \text { bio }}\right)$ that partly offsets the decrease.

In the OMZs of the Atlantic, the $\mathrm{O}_{2}$ concentration is projected to slightly increase between 200 and $500 \mathrm{~m}$ depth (i.e., positive $\Delta \mathrm{O}_{2 \mathrm{OMZ}}$, Fig. $8 \mathrm{~b}$ ). At $250 \mathrm{~m}$ depth $\Delta \mathrm{O}_{2 \mathrm{OMZ}}$ shows the maximum increase of $+3 \mathrm{mmolm}^{-3}$. This increase results from the slightly positive balance between a reduced $\mathrm{O}_{2}$ consumption by remineralization and the reduced physical flux of $\mathrm{O}_{2}$ related to air-sea exchange.

A comparison of the spatial distribution of the changes in $\mathrm{O}_{2}$ and phosphate (Fig. 6) points to linkages between $\mathrm{O}_{2}$ changes in the thermocline and changes in the marine biological cycle. In particular, a decrease in primary production, export of organic material and remineralization (see Steinacher et al., 2010) is linked to the projected $\mathrm{O}_{2}\left(f \mathrm{O}_{2}\right)$ increase in the tropical Pacific and Atlantic, and in the Pacific eastern boundary upwelling systems. Regional changes in $\mathrm{O}_{2}$ and phosphate in the thermocline differ among models similarly as for $f \mathrm{O}_{2}$. This reflects differences in how stratification and circulation is changing in the different models and how the balance between remineralization and physical tracer transport is altered in the thermocline. Such changes can reflect complex feedbacks and interactions between the physical and biogeochemical system, but their identification in the seven models is beyond the scope of this study. 


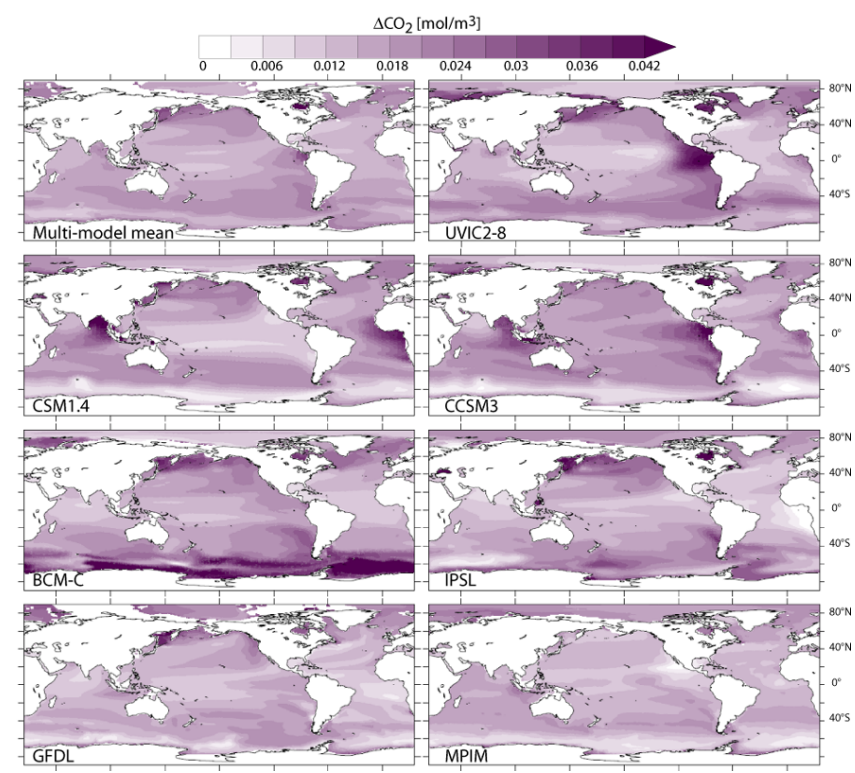

Fig. 9. Projected changes in $\mathrm{CO}_{2}$ in the UML (100 to $600 \mathrm{~m}$ depth) for the SRES A2 scenario. Changes are for 2090s relative to 1870 s (decadal average). The multi-model mean is given in the upper left panel.

The seven models simulate consistently a warming UML under the SRES A2 scenario (Fig. 6), except in a few grid cells. Hence, in the UML the pattern of changes resulting from alteration in the biological cycle is shifted to smaller $\mathrm{O}_{2}$ concentration because of the decrease in $\mathrm{O}_{2}$ solubility due to rising temperatures.

In conclusion, the net changes in $\mathrm{O}_{2}$ depend on changes in the subtle balance between $\mathrm{O}_{2}$ supply by physical transport and $\mathrm{O}_{2}$ consumption by remineralization. Both processes are linked as remineralization is primarily driven by the rate of export of organic matter, which itself depends sensitively on the physical transport of nutrients into the euphotic zone (Steinacher et al., 2010).

\subsection{2 $\mathrm{CO}_{2}$ and DIC}

As expected under a high $\mathrm{CO}_{2}$ emission scenario, a widespread increase in $\mathrm{CO}_{2}$ in the UML (Fig. 9), as well as a shift towards higher values in the $\mathrm{CO}_{2}$ frequency distribution (Fig. 3), is projected by the end of the $21 \mathrm{st}$ century as a consequence of the atmospheric $\mathrm{CO}_{2}$ invasion. The highest peak in the frequency distribution, situated at $0.1-0.2 \mathrm{molm}^{-3}$ in the $1990 \mathrm{~s}$, is found between $0.2-0.4 \mathrm{~mol} \mathrm{~m}^{-3}$ by the end of this century. $\mathrm{CO}_{2}$ is projected to increase by up to $0.045 \mathrm{molm}^{-3}$ and large changes are simulated in the Atlantic and Pacific eastern boundary upwelling systems, in the Bay of Bengal (CSM1.4 and CCSM3) and in the North Pacific (GFDL, IPSL, BCM-C).

The simulated increase in DIC in the UML (Fig. 10) reveals the familiar pattern of high changes in the intermedi-

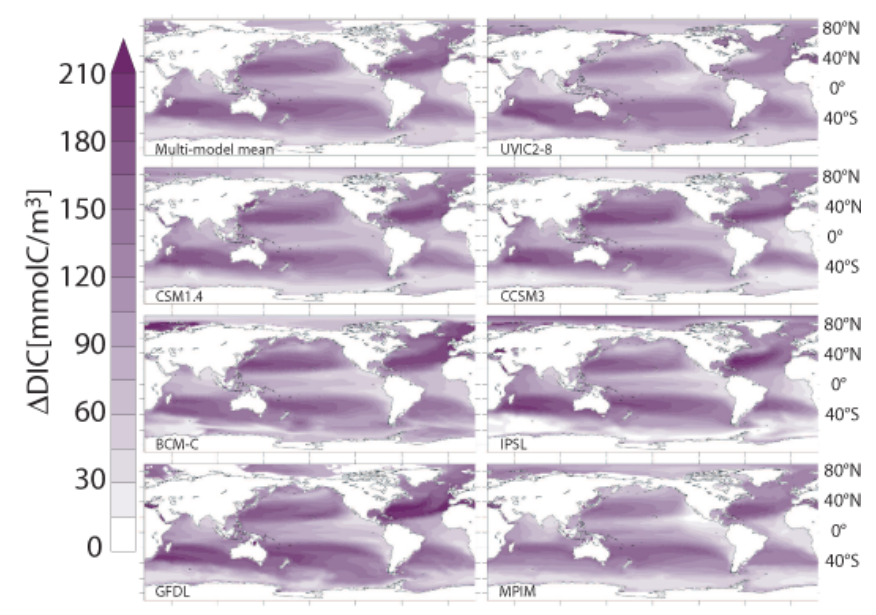

Fig. 10. Projected DIC changes in the UML (100 to $600 \mathrm{~m}$ depth) and for 2090s relative to 1870 s (decadal average). The multi-model mean is given in the upper left panel.

ate water masses around $40^{\circ} \mathrm{N}$ and $40^{\circ} \mathrm{S}$ and in the wellventilated North Atlantic, and relatively small changes in the tropical upwelling regions and around Antarctica. This pattern in DIC change is consistent among the different models and also consistent with observation-based reconstructions for the historical period (Sabine et al., 2004). This increase in DIC is predominantly driven by the invasion of anthropogenic carbon from the atmosphere. Changes in DIC due to the reorganization of the marine biological pump can be approximately quantified by multiplying the simulated changes in phosphate (Fig. 6) with the typical C: P Redfield ratio of 117 after Anderson and Sarmiento (1994) (a value in the middle of the range given by Takahashi et al., 1985; Redfield et al., 1963). These changes are typically much smaller than the simulated DIC increase.

We attribute the $f \mathrm{CO}_{2}$ change to changes in DIC, temperature, ALK, and salinity, following the procedure described in the experimental design section (Fig. 11a, b). The $f \mathrm{CO}_{2}$ increase is predominantly driven by the uptake of anthropogenic $\mathrm{CO}_{2}$ from the atmosphere. On global average, changes in $f \mathrm{CO}_{2}$ in the UML as well as in the deep ocean are predominantly driven by the increase in DIC, with additional contributions resulting from the warming thermocline and minor contributions from changes in alkalinity on the global scale. For example, for CSM1.4 (Fig. 11b) the $f \mathrm{CO}_{2}$ increase at the surface is $\sim 470 \mu \mathrm{atm}$ of which $400 \mu \mathrm{atm}$ are attributed to the change in DIC. At $230 \mathrm{~m}$ depth the total increase is $\sim 560 \mu \mathrm{atm}$; the effect of temperature changes $(+30 \mu \mathrm{atm})$ is one order of magnitude smaller than the DIC contribution $(+510 \mu \mathrm{atm})$. The contributions from changes in salinity, phosphate and silicate to changes in $f \mathrm{CO}_{2}$ are negligible on global average.

In addition to anthropogenic carbon uptake, the change in DIC is also partly attributed to the reorganization of the marine biological cycle. The total $\triangle \mathrm{DIC}$ for the 


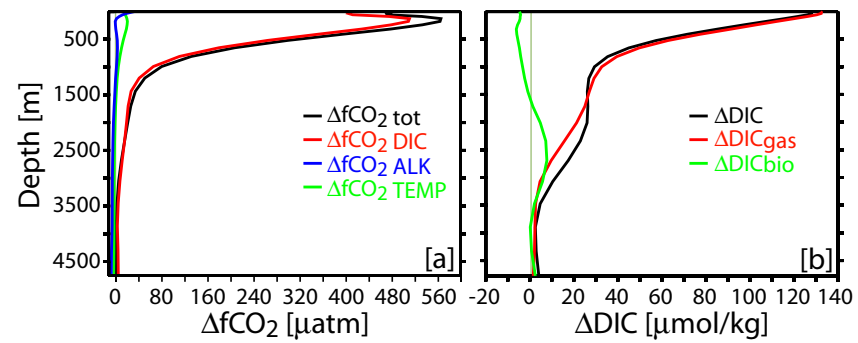

Fig. 11. (a) Depth profile of the $f \mathrm{CO}_{2}$ changes (difference 21001870 ) in the global ocean for CSM1.4. Attribution of global $f \mathrm{CO}_{2}$ changes to different drivers: total $f \mathrm{CO}_{2}$ change (black line), $f \mathrm{CO}_{2}$ changes due to DIC (red), alkalinity (blue), and temperature (green). (b) Depth profile of the Atlantic DIC changes (difference 2100 1870) for CSM1.4. Attribution of Atlantic Ocean DIC changes to different drivers: total DIC changes ( $\triangle \mathrm{DIC}$, black line), DIC changes due to gas exchange $\left(\triangle \mathrm{DIC}_{\text {gas }}\right.$, red) and biological cycle $\left(\Delta \mathrm{DIC}_{\text {bio }}\right.$, green $)$.

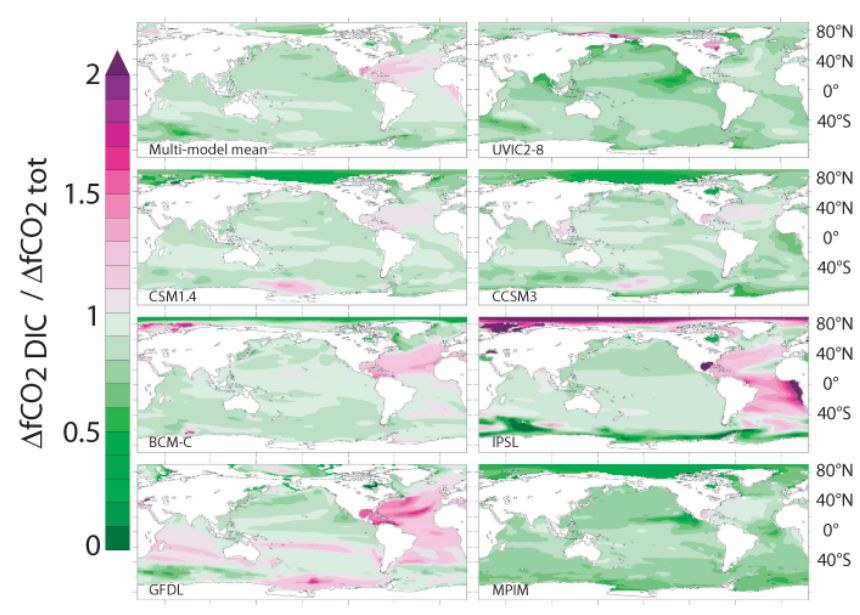

Fig. 12. Fraction of changes in $f \mathrm{CO}_{2}$ that is directly attributable to changes in DIC. Changes are for the UML (100 to $600 \mathrm{~m}$ depth) and for 2090s relative to 1870 s (decadal average). The multi-model mean is given in the upper left panel.

period $1870-2100$ is about $+130 \mathrm{mmolm}^{-3}$ at the surface (Fig. 11b).

A slightly more nuanced picture emerges when considering the contribution by individual drivers to the $f \mathrm{CO}_{2}$ changes in the thermocline on a regional level. In Fig. 12 the ratio between the $f \mathrm{CO}_{2}$ change due to DIC changes $\left(\Delta f \mathrm{CO}_{2 \mathrm{DIC}}\right)$ and the total $f \mathrm{CO}_{2}$ change $\left(\Delta f \mathrm{CO}_{2 \text { tot }}\right)$ for the different models is plotted. The $\Delta f \mathrm{CO}_{2 \mathrm{DIC}} / \Delta f \mathrm{CO}_{2 \text { tot }}$ ratio is generally below one, with the exceptions of the Atlantic and Arctic oceans for IPSL, the Atlantic and Indian basins for GFDL and the North Atlantic for the two NCAR models and BCM-C. This results from the compensating effect of alkalinity changes (negative $\Delta f \mathrm{CO}_{2 \mathrm{ALK}}$ values) in these regions.

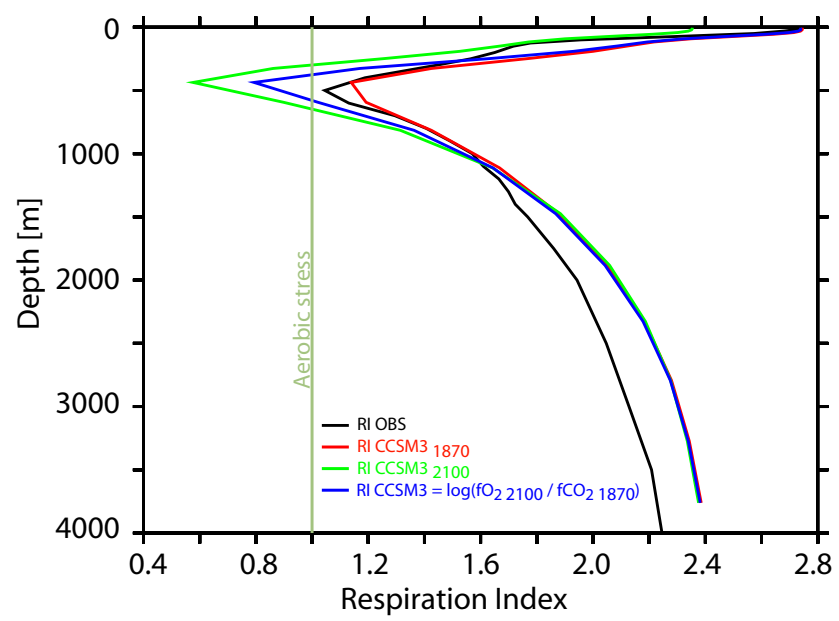

Fig. 13. Regionally averaged $\left(105-115^{\circ} \mathrm{W}, 0-10^{\circ} \mathrm{N}\right)$ depth profile of the respiration index, RI, as simulated by CCSM3 for 1870 (red) and 2100 (green) and as computed from the WOA 09 and GLODAP gridded data (black). The blue line is calculated by using the preindustrial $f \mathrm{CO}_{2}$ values from CCSM3 in combination with projected $f \mathrm{O}_{2}$; the difference between the blue and red line is the 1870-2100 RI change that is attributable to changes in $f \mathrm{O}_{2}$.

In conclusion, all seven models consistently simulate an increase in $f \mathrm{CO}_{2}$ in the UML. Some regional differences remain among the models and are likely related to differences in the thermocline ventilation and its change with time. The $f \mathrm{CO}_{2}$ increase is predominately driven by the uptake of anthropogenic $\mathrm{CO}_{2}$ from the atmosphere.

\subsubsection{Respiration index}

The observation-based RI distribution in the UML (Fig. 4) reveals minima in the eastern tropical Pacific, in the Arabian Sea and in the Bay of Bengal as well as in the eastern upwelling region of the Atlantic and Pacific, while maximum values are found in the Arctic.

Typically, simulated RI in the UML is on average reduced by 0.2 to 0.6 units between 1870 and 2100 (Fig. B3 in Appendix B).

The RI depth profile in the eastern tropical Pacific $\left(105-115^{\circ} \mathrm{W}\right.$ and $\left.0-10^{\circ} \mathrm{N}\right)$ and for CCSM3 is analyzed as an illustrative example to demonstrate the influence of changes in $f \mathrm{O}_{2}$ and $f \mathrm{CO}_{2}$ on $\mathrm{RI}$ (Fig. 13). This region is projected to become part of a large low-RI area in CCSM3. At preindustrial time, simulated RI is well above unity, taken as threshold for aerobic stress, at all depths. RI is projected to decline in the upper $1000 \mathrm{~m}$ and RI falls on average below unity between 300 and $600 \mathrm{~m}$ until 2100 under the SRES A2 scenario. This decline is the result of both a decline in $f \mathrm{O}_{2}$ and an increase in $f \mathrm{CO}_{2}$.

In Fig. 14 the evolution of the volume of five water classes over the period $1870-2100$ is presented. Similarly to what is shown for the volume of low-oxygen waters, the models 

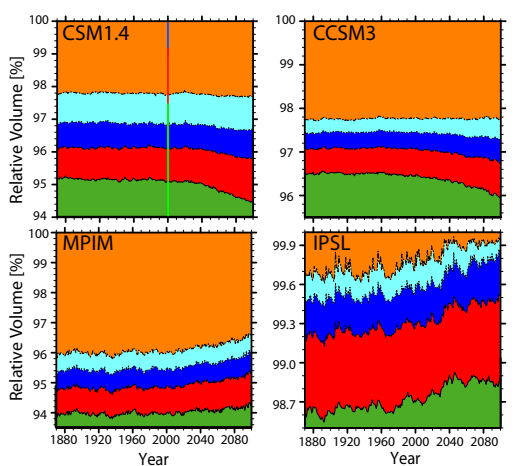
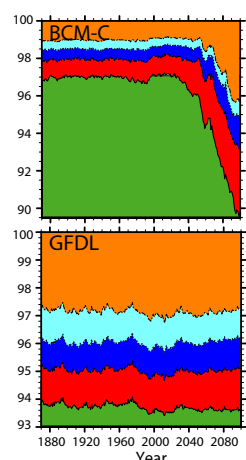

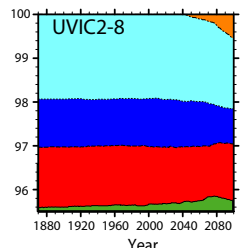

$\mathrm{RI}<0$

$0<\mathrm{R} \|<0.4$

$0.4<$ RI $<0.7$

$0.7<\mathrm{RI}<1$

RI $>1$

Fig. 14. Projected changes in the volume of waters with a respiration index above (green) and below 1 (red to orange), calculated between 100 and $600 \mathrm{~m}$ of depth for the SRES A2 scenario. Volumes are given in percent of the oceanic volume in the $100-600 \mathrm{~m}$ depth range. The observation-based volume is represented in the first panel (vertical bars).

project modest changes in the volume of water with $\mathrm{RI}<0$ (below $1 \%$ ). BCM-C represents an exception, projecting a $3 \%$ expansion, mainly caused by a contraction in the volume with RI $>1(-3.5 \%)$. UVIC2-8 exhibits a $0.6 \%$ increase for water with RI $<0$, while MPIM and IPSL project a $0.6 \%$ and $0.3 \%$ decrease, respectively. The other three models exhibit smaller changes. Diverging changes are found in the volume with RI $>1$, which is projected to shrink by four of the seven models: CCSM3 $(-0.4 \%)$, CSM1.4 $(-0.8 \%)$, GFDL $(-0.4 \%)$ and BCM-C $(-6 \%)$. The other three models project an increase: $+0.4 \%$ for the MPIM, $+0.3 \%$ for the IPSL and $+0.2 \%$ for the UVIC $2-8$, mainly driven by the hypoxic and suboxic waters contraction.

In conclusion, the models do not suggest a widespread expansion of waters with RI below unity, consistent with small changes in the volume of hypoxic and suboxic waters. However, RI declines in the UML in most regions due to the combined influence of rising $f \mathrm{CO}_{2}$ and decreasing $f \mathrm{O}_{2}$ levels.

\section{Summary and discussion}

In this study we have mapped the changes in a few potential stressors for aerobic organisms in the UML for a businessas-usual greenhouse gas emission scenario using a range of Earth System Models. The focus of this study is on the evolution of $\mathrm{CO}_{2}, f \mathrm{CO}_{2}, \mathrm{O}_{2}$, and $f \mathrm{O}_{2}$. Changes in these variables come in combination with changes in other environmental parameters, including a rise in temperature and hydrogen ion concentrations, and implied changes in the speciation of trace metals and other acid-base relationships. These collective changes likely influence the performance and functioning of marine organisms in systematic and synergistic ways. There exists a range of studies discussing projections of $\mathrm{pH}$ and calcium carbonate saturation state under future anthropogenic carbon emission and global warming, and we refer the reader to the literature for further details (e.g., Kleypas et al., 1999; Orr et al., 2005; Steinacher et al., 2009; Frölicher and Joos, 2010; Joos et al., 2011).
The Earth System Models represent the interactions between the physical climate system, biogeochemical cycles, and marine ecosystems under global warming. The limitations in projecting $\mathrm{O}_{2}$ changes arise from the limited understanding of the marine biological processes and the uncertainties about the future evolution of production/remineralization and marine ecosystem functions under rising $\mathrm{CO}_{2}$ (Oschlies et al., 2008; Steinacher et al., 2010). Changes in nutrient fluxes from land to coastal zones and increasing atmospheric nitrogen deposition (Duce et al., 2008) - which can result in local eutrophication and $\mathrm{O}_{2}$ depletion are not included. An intrinsic difficulty is the complexity and multitude of interactions and teleconnections. Gnanadesikan et al. (2012) analyze the $\mathrm{O}_{2}$ changes in GFDL in detail. They identify an additional supply of $\mathrm{O}_{2}$ along isopycnals that is fed by changes in convection and vertical mixing associated with salinification of the surface ocean off Chile. Their results suggest that the simulated changes in the volume of suboxic water in climate models can depend sensitively on changes in the heat and salt balance in nearby convective regions and thus on the patterns of global warming and precipitation minus evaporation. These authors examine also the pattern of the change in advective supply in GFDL and find that low-latitude $\mathrm{O}_{2}$ changes are driven by a decline in net upwelling across $1500 \mathrm{~m}$ with more influence from high- $\mathrm{O}_{2}$, low-nutrient, young surface waters and less from the older low- $\mathrm{O}_{2}$, high-nutrient deep waters.

For CSM1.4, Frölicher et al. (2009) identify a significant warming of the ocean and a decreasing trend of ocean ventilation, which both tend to lower oceanic $\mathrm{O}_{2}$, as well as a decreasing trend in organic matter production, export and remineralization, which tend to increase subsurface $\mathrm{O}_{2}$ and to decrease $\mathrm{O}_{2}$ production at surface. These authors also highlight the role of variability related to climate modes such as the North Atlantic Oscillation and the Pacific Decadal Oscillation and to volcanic forcing. The models simulate consistently an increase in upper ocean temperature, carbon dioxide, and a decrease in $\mathrm{pH}$ and in the global $\mathrm{O}_{2}$ inventory. 
As expected under a high-emission scenario, a widespread increase of $\mathrm{CO}_{2}$ in the UML is projected. The increase in $\mathrm{CO}_{2}$ is primarily the direct result of the invasion of anthropogenic carbon from the atmosphere, and it is mainly responsible for the widespread decrease in RI outside low $\mathrm{O}_{2}$ regions. $\mathrm{RI}$ in the UML is on depth average reduced by 0.2 to 0.6 units.

Changes in dissolved $\mathrm{O}_{2}$ (and $f \mathrm{O}_{2}$ ) are overall relatively small compared to the changes in $\mathrm{CO}_{2}$ (and $f \mathrm{CO}_{2}$ ). The frequency distribution of $\mathrm{O}_{2}$ in the UML is projected to change little over this century even for the high emission A2 scenario, a result that is consistent across the seven models. But projected changes in $\mathrm{O}_{2}$ and dissolved $\mathrm{O}_{2}$ in the UML are regionally of opposite sign. At least five out of seven models simulate in the UML a decrease in $\mathrm{O}_{2}$ in the Southern Ocean, in the northern North Atlantic and North Pacific and in most of the subtropical Pacific and subtropical Indian Ocean, whereas $\mathrm{O}_{2}$ in the UML is projected to increase in the equatorial and subtropical Southeast Atlantic, off California, in the Caribbean and tropical Indian Ocean in the multi-model average. Projected changes in the volume of hypoxic waters $\left(<50 \mathrm{mmolm}^{-3}\right)$ are small and within $\pm 7 \%$ in the seven models. Similarly, projected changes in suboxic waters are small. Analogously to the evolution of the volume occupied by low- $\mathrm{O}_{2}$ waters, in general only small changes are projected for the volume of waters with a low RI.

The dominating mechanisms leading to changes in temperature and $\mathrm{CO}_{2}$ versus those that affect $\mathrm{O}_{2}$ in the UML are fundamentally different under rising anthropogenic greenhouse gas emissions. The decadal-to-century scale uptake of $\mathrm{CO}_{2}$ and heat by the ocean is driven "top down" by the increase in emissions of anthropogenic $\mathrm{CO}_{2}$ and greenhouse gases that cause atmospheric $\mathrm{CO}_{2}$ and radiative forcing to rise. The resulting perturbations in the air-sea temperature and $\mathrm{CO}_{2}$ gradients cause a net flux of heat and $\mathrm{CO}_{2}$ from the atmosphere to the ocean. The temperature and $\mathrm{CO}_{2}$ content of the surface ocean increase and these perturbations are further penetrating the ocean by physical transport (advection, convection, diffusion). However, due to different uptake of $\mathrm{CO}_{2}$ by the land, individual models are forced by different atmospheric $p \mathrm{CO}_{2}$, even though emissions are identical.

The partial pressure or fugacity of $\mathrm{O}_{2}$ in the surface ocean is, except for areas under sea ice, very close to the almost constant atmospheric $\mathrm{O}_{2}$ partial pressure. The typical time scale to equilibrate the well-mixed surface layer with atmospheric $\mathrm{O}_{2}$ is roughly one month - much shorter than the multi-decadal ventilation time scales of the thermocline. Thus, in contrast to $\mathrm{CO}_{2}$ or $\mathrm{pH}$ and temperature, $f \mathrm{O}_{2}$ in the surface layer does hardly vary over multi-decadal timescales. The long-term changes in $f \mathrm{O}_{2}$ and $\mathrm{O}_{2}$ within the thermocline reflect changes in the subtle balance between $\mathrm{O}_{2}$ supply from the surface layer to the thermocline, $\mathrm{O}_{2}$ consumption by the remineralization of organic matter within the thermocline, and advection and diffusion of low- $\mathrm{O}_{2}$ water masses from depth. In general, the models project an increase in stratification and a reduction in surface-to-deep tracer exchange under global warming in mid- and low latitudes (Steinacher et al., 2010). In turn there is a decrease in $\mathrm{O}_{2}$ advection to the thermocline, as well as nutrient supply to the surface ocean, production, export, remineralization, and $\mathrm{O}_{2}$ consumption within the thermocline. Remineralization rates are largely driven by the vertical flux of organic particles that settle due to gravitation, whereas tracer transport has typically a large horizontal component, resulting from advection and diffusion along the sloping layers of equal density. Not surprisingly then, the net balance of these opposing processes in terms of $f \mathrm{O}_{2}$ and $\mathrm{O}_{2}$ changes are regionally distinct.

We conclude that temperature, DIC and $\mathrm{CO}_{2}$ will continue to rise, and $\mathrm{pH}$ and calcium carbonate saturation will continue to decrease in most regions in the thermocline. The link between these large-scale and substantial environmental changes and anthropogenic carbon emissions is firmly established and well understood. In contrast, changes in dissolved $\mathrm{O}_{2}$ resulting from global warming appear relatively small, regionally different, and uncertain. This calls for a distinction of virtually certain ocean warming and acidification versus the postulated deoxygenation of thermocline waters in response to anthropogenic climate change. The challenge is in the observational detection as well as in correct representation of the subtle changes in the balance between $\mathrm{O}_{2}$ supply to the thermocline by physical mixing and advection, and $\mathrm{O}_{2}$ consumption by remineralization of organic material.

\section{Appendix A}

\section{Models}

\section{A1 IPSL}

The IPSL-CM4-LOOP (IPSL) model consists of the Laboratoire de Météorologie Dynamique atmospheric model (LMDZ-4) with a horizontal resolution about $3^{\circ} \times 3^{\circ}$ and 19 vertical levels (Hourdin et al., 2006), coupled to the OPA-8 ocean model with a horizontal resolution of $2^{\circ} \times 2^{\circ} \cdot \cos \phi$ and 31 vertical levels and the LIM sea ice model (Madec et al., 1998). The terrestrial biosphere is represented by the global vegetation model ORCHIDEE (Krinner et al., 2005) and the marine carbon cycle is simulated by the PISCES model (Aumont et al., 2003). PISCES simulates the cycling of carbon, oxygen, and the major nutrients determining phytoplankton growth $\left(\mathrm{PO}_{4}^{3-}, \mathrm{NO}_{3}^{-}, \mathrm{NH}_{4}^{+}, \mathrm{Si}, \mathrm{Fe}\right)$. The model has two phytoplankton size classes (small and large), representing nanophytoplankton and diatoms, as well as two zooplankton size classes (small and large), representing microzooplankton and mesozooplankton. For all species the $\mathrm{C}: \mathrm{N}: \mathrm{P}$ ratios are assumed constant $(122: 16: 1$, Takahashi et al., 1985), while the internal ratios of $\mathrm{Fe}: \mathrm{C}, \mathrm{Chl}: \mathrm{C}$, and $\mathrm{Si}: \mathrm{C}$ of phytoplankton are predicted by the model. Phytoplankton growth is limited by the availability of nutrients and 
light. For a more detailed description of the PISCES model see Aumont and Bopp (2006) and Gehlen et al. (2006). Further details and results from the fully coupled model simulation of the IPSL-CM4-LOOP model are given in Friedlingstein et al. (2006).

\section{A2 MPIM}

The Earth System Model employed for this study at the Max Planck Institute for Meteorology (MPIM) consists of the ECHAM5 (Roeckner et al., 2006) atmospheric model with 31 levels with the embedded JSBACH terrestrial biosphere model and the MPIOM physical ocean model, which includes a sea ice model (Marsland et al., 2003) and the Hamburg Ocean Carbon Cycle model HAMOCC5.1 marine biogeochemistry model (Maier-Reimer, 1993; Six and Maier-Reimer, 1996; Maier-Reimer et al., 2005). The coupling of the marine and atmospheric model components, and in particular the carbon cycles, is achieved by using the OASIS coupler. HAMOCC5.1 is implemented into the MPIOM physical ocean model configuration using a curvilinear coordinate system with a $1.5^{\circ}$ nominal resolution where the North Pole is placed over Greenland, thus providing relatively high horizontal resolution in the Nordic seas. The vertical resolution is 40 layers, with higher resolution in the upper part of the water column $(10 \mathrm{~m}$ at the surface to $13 \mathrm{~m}$ at $90 \mathrm{~m}$ ). A detailed description of HAMOCC5.1 can be found in Maier-Reimer et al. (2005). The marine biogeochemical model HAMOCC5.1 is designed to address largescale, long-term features of the marine carbon cycle, rather than to give a complete description of the marine ecosystem. Consequently, HAMOCC5.1 is a NPZD model with one phytoplankton group (implicitly divided into calcite (coccolithophorids) and opal (diatoms) producers and flagellates), one zooplankton species, and particulate and dissolved dead organic carbon pools. The model contains over 30 biogeochemical tracers, which include dissolved inorganic carbon, total alkalinity, oxygen, nitrate, phosphate, silicate, iron, phytoplankton and zooplankton.

\section{A3 CSM1.4}

The physical core of the NCAR CSM1.4 carbon climate model (Doney et al., 2006; Fung et al., 2005) is a modified version of the NCAR CSM1.4 coupled physical model, consisting of ocean, atmosphere, land and sea ice components integrated via a flux coupler without flux adjustments (Boville et al., 2001; Boville and Gent, 1998). The atmospheric model CCM3 is run with a horizontal resolution of $3.75^{\circ}$ and 18 levels in the vertical (Kiehl et al., 1998). The ocean model is the NCAR CSM Ocean Model (NCOM) with 25 levels in the vertical and a resolution of $3.6^{\circ}$ in longitude and $0.8^{\circ}$ to $1.8^{\circ}$ in latitude (Gent et al., 1998). The sea ice component model runs at the same resolution as the ocean model, and the land surface model runs at the same resolu- tion as the atmospheric model. The CSM1.4-carbon model includes a derivate of the OCMIP-2 (Ocean Carbon Cycle Model Intercomparison Project Phase 2) ocean biogeochemistry model (Najjar et al., 2007). In the ocean model, the biological source-sink term has been changed from a nutrient restoring formulation to a prognostic formulation inspired by Maier-Reimer (1993). Biological production is modulated by temperature $(T)$, surface solar irradiance $(I)$, mixed layer depth (MLD), and macro- and micro-nutrients $\left(\mathrm{PO}_{4}^{3-}\right.$ and iron). The $\mathrm{C}: \mathrm{P}$ ratio is constant and set to 117 (Anderson and Sarmiento, 1994).

\section{A4 CCSM3}

The NCAR CCSM3 carbon is a coupled climate model that uses no flux correction (Collins et al., 2006b). The model components are the Community Atmosphere Model version 3 (CAM3, Collins et al., 2006a), the Community Land Model version 3 (CLM3, Dickson et al., 2006), the Parallel Ocean Program version 1.4 (POP1.4, Danabasoglu et al., 2006), and the Community Sea Ice Model (CSIM, Holland et al., 2006). In CCSM3 carbon, the land model is on the same horizontal grid as CAM3 (T31) and the sea ice model shares the same horizontal grid as the ocean model (gx3v5). Overall, CCSM3 carbon includes improvements in the parametrization of the physics as well as the biogeochemical cycles compared to earlier NCAR model versions (e.g., NCAR CSM1.4-carbon). New treatments of cloud processes, aerosol radiative forcing, land-atmosphere fluxes, ocean mixed layer processes, and sea ice dynamics are included. The CCSM3 Biogeochemical Elemental Cycling (BEC) model includes several phytoplankton functional groups, one zooplankton group, semilabile dissolved organic matter, and sinking particles (Moore et al., 2004). Model-data skill metrics for the simulated marine ecosystem in uncoupled ocean experiments are reported in Doney et al. (2009). The BEC includes explicit cycling of $\mathrm{C}, \mathrm{N}, \mathrm{P}, \mathrm{Fe}, \mathrm{Si}, \mathrm{O}$ and alkalinity. Phytoplankton functional groups include diatoms, diazotrophs, picoplankton, and coccolithophores. Phytoplankton $\mathrm{Fe} / \mathrm{C}, \mathrm{Chl} / \mathrm{C}$, and $\mathrm{Si} / \mathrm{C}$ ratios adjust dynamically to ambient nutrient and light, while the C/N/P ratios are fixed within each group (Moore et al., 2004). The CCSM3 ocean circulation model is a coarse resolution version of the Parallel Ocean Program (POP) model with longitudinal resolution of 3.6 degrees and a variable latitudinal resolution from $1-2^{\circ}$. There are 25 vertical levels with eight levels in the upper $103 \mathrm{~m}$ (Smith and Gent, 2004; Yeager et al., 2006).

\section{A5 BCM-C}

The Bergen Earth System Model coupled with terrestrial and oceanic carbon cycle models (BCM-C) is described in detail in Tjiputra et al. (2010), where regional climate-carbon cycle feedbacks are assessed. The physical ocean part of the BCM$\mathrm{C}$ model is based on the Miami Isopycnic Coordinate Ocean 
Model (MICOM) and is documented in Bleck and Smith (1990) and Bleck et al. (1992). Updates to the model code are described in Bentsen et al. (2004) and Assmann et al. (2010). With the exception of the equatorial region, the grid configuration employed here is almost regular with a horizontal grid spacing of approximately $2.4^{\circ} \times 2.4^{\circ}$. In order to better resolve the dynamics near the equator, the horizontal spacing in the meridional direction is gradually decreased to 0.8 along the equator. The marine carbon cycle is represented by the HAMOCC5.1 model (Maier-Reimer et al., 2005). However, the biogeochemical was refined and adapted for isopycnic coordinates (Assmann et al., 2010). The current version of the model includes an NPZD-type (nutrient, phytoplankton, zooplankton and detritus) ecosystem model following Six and Maier-Reimer (1996). The inorganic carbon chemistry in the HAMOCC5.1 model is based on Maier-Reimer and Hasselmann (1987) and is updated with the OCMIP (Ocean Carbon Cycle Model Intercomparison Project) carbon chemistry protocols.

\section{A6 GFDL}

The ESM2.1 Earth System Model was developed by the Geophysical Fluid Dynamics Laboratory (GFDL) in Princeton, USA, the physical fundament of the model being the CM2.1 coupled climate model (Delworth et al., 2006). In a fully coupled state, the model includes components for ocean (MOM4 Griffies et al., 2004), atmosphere (AM2.1) and terrestrial biosphere (LM3 Anderson et al., 2004). LM3 is based on potential vegetation, so no land use is included. MOM-4 has 50 vertical levels, its spatial resolution is nominally $1^{\circ}$ globally, with a higher resolution of $1 / 3^{\circ}$ near the equator. Ocean biogeochemistry is represented by TOPAZ (Dunne et al., 2005) and includes a number of major nutrients (N, $\mathrm{P}, \mathrm{Si}$ and $\mathrm{Fe}$ ), both labile and semi-labile dissolved organic pools and parameterizations to represent the microbial loop (Henson et al., 2010). The ocean ecosystem is based on three classes of phytoplankton, biological production is modeled as a function of $\mathrm{Chl}: \mathrm{C}$ ratios and limited by nutrients and light. Also, a simplified version of the ocean iron cycle is included, comprising biological uptake and remineralization, particle sinking and scavenging and adsorption/desorption.

\section{A7 UVIC2-8}

The UVIC2-8 model is the University of Victoria (UVic) Earth System Climate Model (Weaver et al., 2001) in the Redfield stoichiometry configuration described by Oschlies et al. (2008). The oceanic component is a fully threedimensional primitive-equation model with nineteen levels in the vertical, ranging from $50 \mathrm{~m}$ thickness near the surface to $500 \mathrm{~m}$ in the deep ocean. It contains a simple marine ecosystem model with the two major nutrients nitrate and phosphate and two phytoplankton classes, nitrogen fixers and other phytoplankton, with the former being limited only by phosphate. The trace nutrient iron is not explicitly included in the model. By tuning the biological parameters, in particular the relatively low maximum phytoplankton growth rate $\left(0.13\right.$ day $^{-1}$ at $\left.0^{\circ} \mathrm{C}\right)$, the model nevertheless achieves a reasonable fit to observed biogeochemical tracer distributions (Schmittner et al., 2008). Organic matter is produced, processed, and remineralized according to a fixed elemental stoichiometry of $\mathrm{C}: \mathrm{N}: \mathrm{P}=112: 16: 1$. The ocean component is coupled to a single-level energy-moisture balance model of the atmosphere and a dynamic-thermodynamic sea ice component. The terrestrial vegetation and carbon cycle component is based on the Hadley Centre's TRIFFID model (Cox et al., 2000). All model components use a common horizontal resolution of $1.8^{\circ}$ latitude $\times 3.6^{\circ}$ longitude.

\section{Appendix B}

\section{Projected changes in RI - additional figure}

Figure B3 illustrates the projected RI changes in the UML by year 2100. The largest reductions are projected by BCM-C in the Southern Ocean, the North Atlantic and Pacific. Most of the decrease is related to the increase in $f \mathrm{CO}_{2}$ in many areas. $\mathrm{RI}$ is projected to increase in the eastern South Atlantic in most models. This is consistent with the projected changes in $f \mathrm{O}_{2}$ in this region. The increase in $f \mathrm{O}_{2}$ dominates over the projected increase in $f \mathrm{CO}_{2}$ in this low-oxygen region.

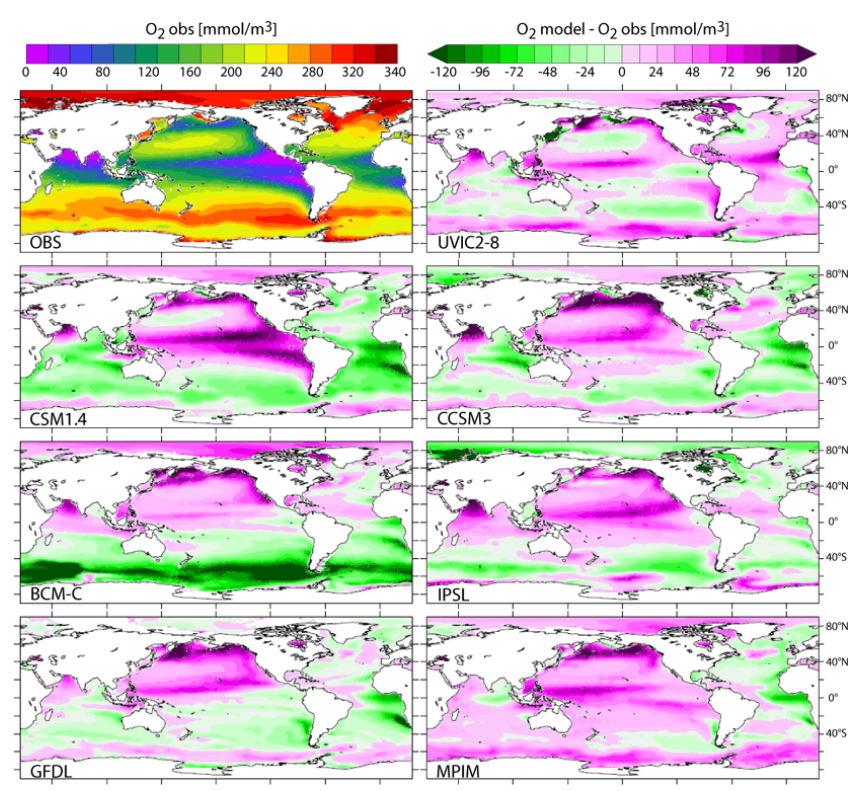

Fig. B1. $\mathrm{O}_{2}$ in the UML (100-600 $\mathrm{m}$ depth average). Upper left: $\mathrm{O}_{2}$ as calculated from WOA 09 dissolved oxygen, temperature and salinity. The other panels represent the difference between observation-based estimates and the modeled distributions (1990-1999 mean) of $\mathrm{O}_{2}$. 


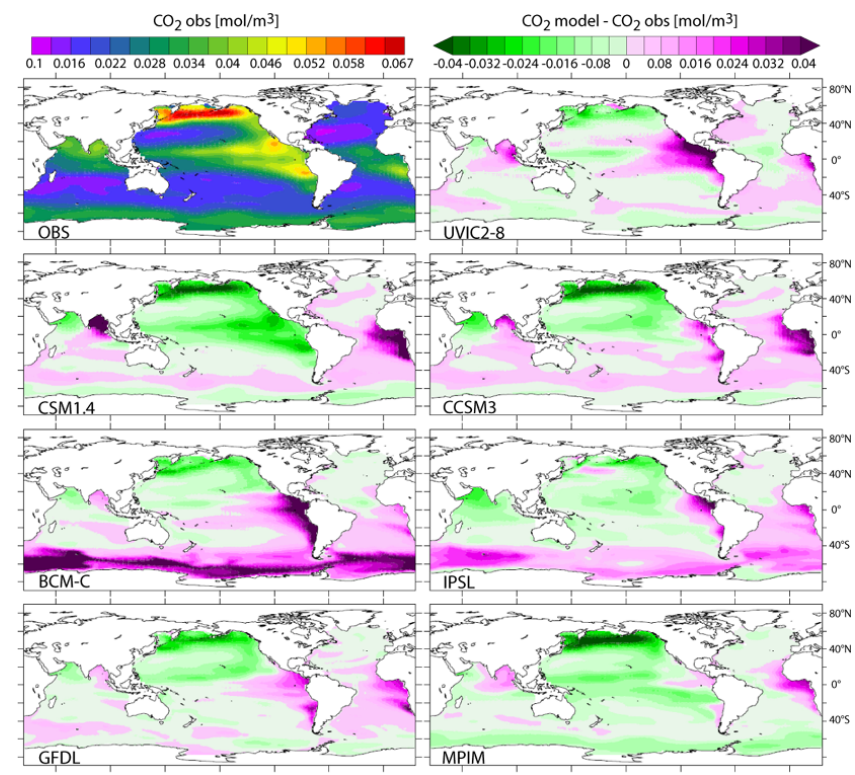

Fig. B2. $\mathrm{CO}_{2}$ in the UML (100-600 $\mathrm{m}$ depth average). Upper left: $\mathrm{CO}_{2}$ as calculated from GLODAP alkalinity and DIC, WOA 09 temperature, salinity, phosphate and silicate. The other panels represent the difference between observation-based and modeled distributions (1990-1999 mean) of $\mathrm{CO}_{2}$.

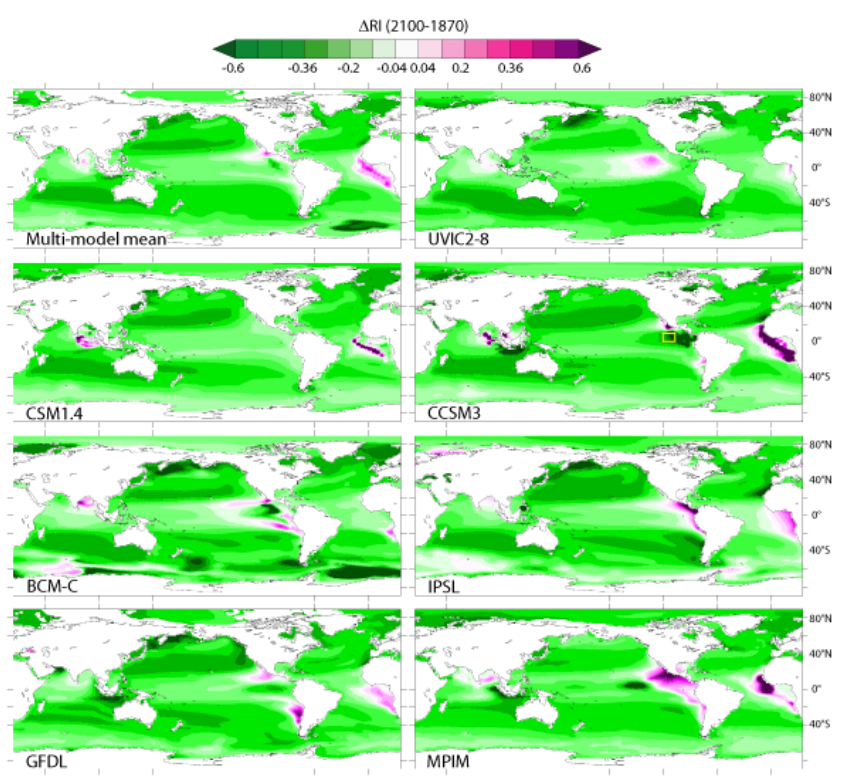

Fig. B3. Projected changes in the respiration index, RI, in the UML (100 to $600 \mathrm{~m}$ depth) for the SRES A2 scenario. Changes are for 2100 relative to 1870 . The multi-model mean change is given in the upper left panel. The yellow box refers to the region of Fig. 13.
Acknowledgements. This work was funded by the "European Project on Ocean Acidification" EPOCA (211384) and by the European Project CARBOCHANGE (264879), which both received funding from the European Commission's Seventh Framework Programme (FP7/2007-2013), and by the Swiss National Science Foundation. Simulations with CSM1.4 and CCSM3 were carried out at the Swiss National Supercomputing Centre (CSCS) in Manno, Switzerland. We thank S. C. Doney, I. Fung, K. Lindsay, J. John and colleagues for providing the CSM1.4-carbon code. MPIM computations were done at Deutsches Klimarechenzentrum (DKRZ). This publication is also listed as publication A418 from the Bjerknes Centre for Climate Research. University of Bergen and Uni Klima further were supported through EU FP7 project COMBINE (grant agreement no. 226520), the Research Council of Norway funded project CarboSeason (185105/S30), and the Norwegian Metacenter for Computational Science and Storage Infrastructure (NOTUR and Norstore, "Biogeochemical Earth System Modelling" projects nn2980k and ns2980k). This is a contribution to core project BIOFEEDBACK of the Centre for Climate Dynamics (SKD) at Bergen. T. L. Frölicher was supported by the NF-UBC Nereus Program.

Edited by: G. Herndl

\section{References}

Anderson, L. A. and Sarmiento, J. L.: Redfield ratios of remineralization determined by nutrient data-analysis, Global Biogeochem Cy., 8, 65-80, 1994.

Anderson, J., Balaji, V., Broccoli, A., Cooke, W., Delworth, T., Dixon, K., Donner, L., Dunne, K., Freidenreich, S., Garner, S., Gudgel, R., Gordon, C., Held, I., Hemler, R., Horowitz, L., Klein, S., Knutson, T., Kushner, P., Langenhost, A., Lau, N., Liang, Z., Malyshev, S., Milly, P., Nath, M., Ploshay, J., Ramaswamy, V., Schwarzkopf, M., Shevliakova, E., Sirutis, J., Soden, B., Stern, W., Thompson, L., Wilson, R., Wittenberg, A., Wyman, B., and GFDL Global Atmospheric Model Dev: The new GFDL global atmosphere and land model AM2-LM2: evaluation with prescribed SST simulations, J. Climate, 17, 46414673, doi:10.1175/JCLI-3223.1, 2004.

Antonov, J. I., Seidov, D., Boyer, T. P., Locarnini, R. A., Mishonov, A. V., Garcia, H. E., Baranova, O. K., Zweng, M. M., and Johnson, D. R.: World Ocean Atlas 2009, Volume 2: Salinity, in: The Global Ocean Carbon Cycle, S. Levitus, Ed. NOAA Atlas NESDIS 69, US Government Printing Office, Washington, DC, 184 pp., 2010.

Assmann, K. M., Bentsen, M., Segschneider, J., and Heinze, C.: An isopycnic ocean carbon cycle model, Geosci. Model Dev., 3, 143-167, doi:10.5194/gmd-3-143-2010, 2010.

Aumont, O. and Bopp, L.: Globalizing results from ocean in situ iron fertilization studies, Global Biogeochem Cy., 20, GB2017, doi:10.1029/2005GB002591, 2006.

Aumont, O., Maier-Reimer, E., Blain, S., and Monfray, P.: An ecosystem model of the global ocean including $\mathrm{Fe}, \mathrm{Si}, \mathrm{P}$ colimitations, Global Biogeochem Cy., 17, GB1060, 2003.

Bentsen, M., Drange, H., Furevik, T., and Zhou, T.: Simulated variability of the Atlantic meridional overturning circulation, Clim. Dynam., 22, 701-720, doi:10.1007/s00382-004-0397-x, 2004. 
Bianchi, D., Dunne, J., Sarmiento, J., and Galbraith, E.: Data-based estimates of suboxia, denitrification and $\mathrm{N}_{2} \mathrm{O}$ production in the ocean, and their sensitivities to change, Global Biogeochem Cy., 26, 6550-6555, 2012.

Bindoff, N., Willebrand, J., Artale, V., Cazenave, A., Gregory, J., Gulev, S., Hanawa, K., Le Quere, C., Levitus, S., Norjiri, Y., Shum, C., Talley, L., and Unnikrishnan, A.: Observations: oceanic climate change and sea level, in: Climate Change 2007: The Physical Science Basis, Contribution of Working Group I to the Fourth Assessment Report of the Intergovernmental Panel on Climate Change, edited by: Solomon, S., Qin, D., Manning, M., Chen, Z., Marquis, M., Averyt, K. B., Tignor, M., and Miller, H. L., Tech. Rep., Intergovernmental Panel on Climate Change, Cambridge University Press, Cambridge, United Kingdom and New York, NY, USA, 2007.

Bleck, R. and Smith, L.: A wind-driven isopycnic coordinate model of the North and Equatorial Atlantic Ocean, 1. Model development and supporting experiments, J. Geophys. Res., 95, 32733285, doi:10.1029/JC095iC03p03273, 1990.

Bleck, R., Rooth, C., Hu, D., and Smith, L.: Salinity-driven thermocline transients in a wind- and thermohaline-forced isopycnic coordinate model of the North Atlantic, J. Phys. Oceanogr., 22, 1486-1505, 1992.

Bopp, L., Le Quéré, C., Heimann, M., Manning, A. C., and Monfray, P.: Climate-induced oceanic oxygen fluxes: implications for the contemporary carbon budget, Global Biogeochem Cy., 16, 1022, doi:10.1029/2001GB001445, 2002.

Boville, B. and Gent, P.: The NCAR Climate System Model, version one, J. Climate, 11, 1115-1130, doi:10.1175/15200442(1998)011<1115:TNCSMV>2.0.CO;2, 1998.

Boville, B., Kiehl, J., Rasch, P., and Bryan, F.: Improvements to the NCAR CSM-1 for transient climate simulations, J. Climate, 14, 164-179, doi:10.1175/15200442(2001)014<0164:ITTNCF>2.0.CO;2, 2001.

Brewer, P. and Peltzer, E.: Limits to marine life, Science, 324, $347-$ 348, doi:10.1126/science.1170756, 2009.

Chan, F., Barth, J. A., Lubchenco, J., Kirincich, A., Weeks, H., Peterson, W. T., and Menge, B. A.: Emergence of anoxia in the California current large marine ecosystem, Science, 319, 920, doi:10.1126/science.1149016, 2008.

Collins, W. D., Rasch, P., Boville, B., Hack, J., McCaa, J., Williamson, D., Briegleb, B., Bitz, C., Lin, S., and Zhang, M.: The formulation and atmospheric simulation of the Community Atmosphere Model version 3 (CAM3), J. Climate, 19, 21442161, doi:10.1175/JCLI3760.1, 2006a.

Collins, W. D., Bitz, C. M., Blackmon, M. L., Bonan, G. B., Bretherton, C. S., Carton, J. A., Chang, P., Doney, S. C., Hack, J. J., Henderson, T. B., Kiehl, J. T., Large, W. G., McKenna, D. S., Santer, B. D., and Smith, R. D.: The Community Climate System Model version 3 (CCSM3), J. Climate, 19, 2122-2143, doi:10.1175/JCLI3761.1, 2006b.

Cox, P., Betts, R., Jones, C., Spall, S., and Totterdell, I.: Acceleration of global warming due to carbon-cycle feedbacks in a coupled climate model, Nature, 408, 184-187, 2000.

Danabasoglu, G., Large, W., Tribbia, J., Gent, P., Briegleb, B., and McWiliams, J.: On multidecadal variability of the Atlantic meridional overturning circulation in the Community Climate System Model version 3, J. Climate, 19, 2347-2365, doi:10.1175/JCLI3742.1, 2006.
Delworth, T., Broccoli, A., Rosati, A., Stouffer, R., Balaji, V., Beesley, J., Cooke, W., Dixon, K., Dunne, J., Dunne, K., Durachta, J., Findell, K., Ginoux, P., Gnanadesikan, A., Gordon, C., Griffies, S., Gudgel, R., Harrison, M., Held, I., Hemler, R., Horowitz, L., Klein, S., Knutson, T., Kushner, P., Langenhorst, A., Lee, H., Lin, S., Lu, J., Malyshev, S., Milly, P., Ramaswamy, V., Russell, J., Schwarzkopf, M., Shevliakova, E., Sirutis, J., Spelman, M., Stern, W., Winton, M., Wittenberg, A., Wyman, B., Zeng, F., and Zhang, R.: GFDL's CM2 global coupled climate models, Part I: Formulation and simulation characteristics, J. Climate, 19, 643-674, 2006.

Deutsch, C., Brix, H., Ito, T., Frenzel, H., and Thompson, L.: Climate-forced variability of ocean hypoxia, Science, 333, 336339, doi:10.1126/science.1202422, 2011.

Dickson, R. E., Oleson, K. W., Bonan, G., Hoffman, F., Thornton, P., Vertenstein, M., Yang, Z.-L., and Zeng, X.: The community land model and its climate statistics as a component of the community climate system model, J. Climate, 19, 2302-2324, doi:10.1175/JCLI3742.1, 2006.

Doney, S. C., Lindsay, K., Fung, I., and John, J.: Natural variability in a stable, 1000-yr global coupled climate-carbon cycle simulation, J. Climate, 19, 3033-3054, 2006.

Doney, S. C., Lima, I., Moore, J. K., Lindsay, K., Behrenfeld, M. J., Westberry, T. K., Mahowald, N., Glover, D. M., and Takahashi, T.: Skill metrics for confronting global upper ocean ecosystem-biogeochemistry models against field and remote sensing data, J. Marine Syst., 76, 95-112, 2009.

Duce, R. A., LaRoche, J., Altieri, K., Arrigo, K. R., Baker, A. R., Capone, D. G., Cornell, S., Dentener, F., Galloway, J., Ganeshram, R. S., Geider, R. J., Jickells, T., Kuypers, M. M., Langlois, R., Liss, P. S., Liu, S. M., Middelburg, J. J., Moore, C. M., Nickovic, S., Oschlies, A., Pedersen, T., Prospero, J., Schlitzer, R., Seitzinger, S., Sorensen, L. L., Uematsu, M., Ulloa, O., Voss, M., Ward, B., and Zamora, L.: Impacts of atmospheric anthropogenic nitrogen on the open ocean, Science, 320, 893-897, 2008.

Dunne, J., Armstrong, R., Gnanadesikan, A., and Sarmiento, J.: Empirical and mechanistic models for the particle export ratio, Global Biogeochem Cy., 19, GB4026, doi:10.1029/2004GB002390, 2005.

Duteil, O. and Oschlies, A.: Sensitivity of simulated extent and future evolution of marine suboxia to mixing intensity, Geophys. Res. Lett., 38, L06607, doi:10.1029/2011GL046877, 2011.

Emerson, S., Mecking, S., and Abell, J.: The biological pump in the subtropical North Pacific Ocean: nutrient sources, Redfield ratios, and recent changes, Global Biogeochem Cy., 15, 535-554, 2001.

Emerson, S., Watanabe, Y., Ono, T., and Mecking, S.: Temporal trends in apparent oxygen utilization in the upper pycnocline of the North Pacific: 1980-2000, J. Oceanogr., 60, 139-147, 2004.

Friedlingstein, P., Cox, P., Betts, R., Bopp, L., Von Bloh, W., Brovkin, V., Cadule, P., Doney, S., Eby, M., Fung, I., Bala, G., John, J., Jones, C., Joos, F., Kato, T., Kawamiya, M., Knorr, W., Lindsay, K., Matthews, H. D., Raddatz, T., Rayner, P., Reick, C., Roeckner, E., Schnitzler, K. G., Schnur, R., Strassmann, K., Weaver, A. J., Yoshikawa, C., and Zeng, N.: Climate-carbon cycle feedback analysis: results from the $\mathrm{C}^{4} \mathrm{MIP}$ model intercomparison, J. Climate, 19, 3337-3353, 2006. 
Frölicher, T. L. and Joos, F.: Reversible and irreversible impacts of greenhouse gas emissions in multi-century projections with the NCAR global coupled carbon cycle-climate model, Clim. Dynam., 35, 1439-1459, 2010.

Frölicher, T. L., Joos, F., Plattner, G. K., Steinacher, M., and Doney, S. C.: Natural variability and anthropogenic trends in oceanic oxygen in a coupled carbon cycle-climate model ensemble, Global Biogeochem Cy., 23, GB1003, doi:10.1029/2008GB003316, 2009.

Fung, I., Doney, S., Lindsay, K., and John, J.: Evolution of carbon sinks in a changing climate, Proc. Natl. Acad. Sci. USA, 102, 11201-11206, 2005.

Garcia, H. E. and Gordon, L. I.: Oxygen solubility in seawater: better fitting equations, Limnol. Oceanogr., 37, 1307-1312, 1992.

Garcia, H. E., Locarnini, R., Boyer, T., Antonov, J., Baranova, O., Zweng, M., and Johnson, D.: Volume 3: Dissolved Oxygen, Apparent Oxygen Utilization, and Oxygen Saturation, World Ocean Atlas 2009, S. Levitus, Ed. NOAA Atlas NESDIS 70, US Government Printing Office, Washington, DC, 344 pp., 2010a.

Garcia, H. E., Locarnini, R., Boyer, T., Antonov, J., Zweng, M., Baranova, O., and Johnson, D.: Volume 4: Nutrients (phosphate, nitrate, silicate), World Ocean Atlas 2009, edited by: Levitus, S., NOAA Atlas NESDIS 71, US Government Printing Office, Washington, DC, 398 pp., 2010 b.

Gehlen, M., Bopp, L., Emprin, N., Aumont, O., Heinze, C., and Ragueneau, O.: Reconciling surface ocean productivity, export fluxes and sediment composition in a global biogeochemical ocean model, Biogeosciences, 3, 521-537, doi:10.5194/bg-3521-2006, 2006.

Gent, P., Bryan, F., Danabasoglu, G., Doney, S., Holland, W., Large, W., and McWilliams, J.: The NCAR climate system model global ocean component, J. Climate, 11, 1287-1306, 1998.

Gnanadesikan, A., Dunne, J. P., and John, J.: Understanding why the volume of suboxic waters does not increase over centuries of global warming in an Earth System Model, Biogeosciences, 9, 1159-1172, doi:10.5194/bg-9-1159-2012, 2012.

Griffies, S. M., Harrison, M. J., Pacanowski, R. C., and Rosati, A.: A technical guide to MOM4, GFDL Ocean Group Technical Report, Tech. Rep., Geophysical Fluid Dynamics Laboratory, Princeton, USA, 2004.

Gruber, N.: Warming up, turning sour, losing breath: ocean biogeochemistry under global change, Philos. T. Roy. Soc. A, 369, 1980-1996, 2011.

Gruber, N. and Sarmiento, J.: Chapter 9, in: The Sea, edited by: Robinson, A. R., McCarthy, J. J., and Rothschild, B. J., John Wiley \& Sons, Inc., New York, 12, 337-399, 2002.

Helm, K. P., Bindoff, N. L., and Church, J. A.: Observed decreases in oxygen content of the global ocean, Geophys. Res. Lett., 38, L23602, doi:10.1029/2011GL049513, 2011.

Henson, S. A., Sarmiento, J. L., Dunne, J. P., Bopp, L., Lima, I., Doney, S. C., John, J., and Beaulieu, C.: Detection of anthropogenic climate change in satellite records of ocean chlorophyll and productivity, Biogeosciences, 7, 621-640, doi:10.5194/bg-7621-2010, 2010.

Hofmann, A. F. and Peltzer, E. T. and Walz, P. M. and Brewer, P. G.: Hypoxia by degrees: Establishing definitions for a changing ocean, Deep-Sea Res. I, 58, 1212-1226, doi:10.1016/j.dsr.2011.09.004, 2011.
Holland, M. M., Bitz, C. M., Hunke, E. C., Lipscomb, W. H., and Schramm, J. L.: Influence of the sea ice thickness distribution on polar climate in CCSM3, J. Climate, 19, 2398-2414, 2006.

Hourdin, F., Musat, I., Bony, S., Braconnot, P., Codron, F., Dufresne, J.-L., Fairhead, L., Filiberti, M.-A., Friedlingstein, P., Grandpeix, J.-Y., Krinner, G., LeVan, P., Li, Z.-X., and Lott, F.: The LMDZ4 general circulation model: climate performance and sensitivity to parametrized physics with emphasis on tropical convection, Clim. Dynam., 27, 787-813, 2006.

Joos, F., Plattner, G.-K., Stocker, T. F., Körtzinger, A., and Wallace, D.: Trends in marine dissolved oxygen: implications for ocean circulation changes and the carbon budget, EOS T. Am. Geophys. Un., 84, p. 197, doi:10.1029/2003EO210001, 2003.

Joos, F., Frölicher, T. L., Steinarcher, M., and Plattner, G.-K.: Impact of climate change mitigation on ocean acidification projections, in: Ocean acidification, edited by: Gattuso, J.-P. and Hansson, L., Oxford University Press, Oxford, 272-290, 2011.

Keeling, R. F., Körtzinger, A., and Gruber, N.: Ocean deoxygenation in a warming world, Annu. Rev. Marine Sci., 2, 199-229, doi:10.1146/annurev.marine.010908.163855, 2010.

Keller, K., Joos, F., Raible, C., Cocco, V., Frölicher, T., J. P., D., Gehlen, M., Roy, T., Bopp, L., Orr, J., Tjiputra, J., Heinze, C., Segschneider, J., and Metzl, N.: Variability of the ocean carbon cycle in response to the North Atlantic oscillation, Tellus B, 64, 18738, doi:10.3402/tellusb.v64i0.18738, 2012.

Key, R., Kozyr, A., Sabine, C., Lee, K., Wanninkhof, R., Bullister, J., Feely, R., Millero, F., Mordy, C., and Peng, T.: A global ocean carbon climatology: results from Global Data Analysis Project (GLODAP), Global Biogeochem Cy., 18, GB4031, doi:10.1029/2004GB002247, 2004.

Kiehl, J., Hack, J., Bonan, G., Boville, B., Williamson, D., and Rasch, P.: The national center for atmospheric research community climate model: CCM3, J. Climate, 11, 1131-1149, 1998.

Kleypas, J. A., Buddemeier, R. W., Archer, D., Gattuso, J.-P., Langdon, C., and Opdyke, B. N.: Geochemical consequences of increased atmospheric carbon dioxide on coral reefs, Science, 284, 118-120, doi:10.1126/science.284.5411.118, 1999.

Krinner, G., Viovy, N., de Noblet-Ducoudre, N., Ogee, J., Polcher, J., Friedlingstein, P., Ciais, P., Sitch, S., and Prentice, I.: A dynamic global vegetation model for studies of the coupled atmosphere-biosphere system, Global Biogeochem Cy., 19, GB1015, doi:10.1029/2003GB002199, 2005.

Kroeker, K. J., Kordas, R. L., Crim, R. N., and Singh, G. G.: Meta-analysis reveals negative yet variable effects of ocean acidification on marine organisms, Ecol. Lett., 13, 1419-1434, doi:10.1111/j.1461-0248.2010.01518.x, 2010.

Locarnini, R. A., Mishonov, A. V., Antonov, J. I., Boyer, T. P., Garcia, H. E., Baranova, O. K., Zweng, M. M., and Johnson, D. R.: Volume 1: Temperature, in: World Ocean Atlas 2009, S. Levitus, Ed. NOAA Atlas NESDIS 68, US Government Printing Office, Washington, DC, 184 pp., 2010.

Lüger, H., Wanninkhof, R., Wallace, D., and Kortzinger, A.: $\mathrm{CO}_{2}$ fluxes in the subtropical and subarctic North Atlantic based on measurements from a volunteer observing ship, J. Geophys. Res.-Oceans, 111, C06024, doi:10.1029/2005JC003101, 2006.

Madec, G., Delecluse, P., Imbard, M., and Lévy, M.: OPA 8.1 Ocean General Circulation Model reference manual, Note du Pole de modélisation, No11, Tech. Rep., Institut Pierre-Simon Laplace (IPSL), Paris, France, 1998. 
Maier-Reimer, E.: Geochemical cycles in an ocean general circulation model: preindustrial tracer distributions, Global Biogeochem Cy., 7, 645-677, 1993.

Maier-Reimer, E. and Hasselmann, K.: Transport and storage of $\mathrm{CO}_{2}$ in the ocean: an inorganic ocean-circulation carbon cycle model, Clim. Dynam., 2, 63-90, 1987.

Maier-Reimer, E., Kriest, I., Segschneider, J., and Wetzel, P.: The HAMburg Ocean Carbon Cycle model HAMOCC5.1 - Technical description, Berichte zur Erdsystemforschung 14/2005, 14, Tech. Rep., Max-Planck-Institut für Meteorologie, Hamburg, Germany, 2005.

Marsland, S., Haak, H., Jungclaus, J., Latif, M., and Roske, F.: The Max-Planck-Institute global ocean/sea ice model with orthogonal curvilinear coordinates, Ocean Model., 5, 91-127, 2003.

Mayol, E., Ruiz-Halpern, S., Duarte, C. M., Castilla, J. C., and Pelegrí, J. L.: Coupled $\mathrm{CO}_{2}$ and $\mathrm{O}_{2}$-driven compromises to marine life in summer along the Chilean sector of the Humboldt Current System, Biogeosciences, 9, 1183-1194, doi:10.5194/bg9-1183-2012, 2012.

Mecking, S., Warner, M. J., and Bullister, J. L.: Temporal changes in pCFC-12 ages and AOU along two hydrographic sections in the eastern subtropical North Pacific, Deep-Sea Res. I, 53, 169-187, 2006.

Mecking, S., Langdon, C., Feely, R. A., Sabine, C. L., Deutsch, C. A., and Min, D.-H.: Climate variability in the North Pacific thermocline diagnosed from oxygen measurements: an update based on the US CLIVAR/ $/ \mathrm{CO}_{2}$ repeat hydrography cruises, Global Biogeochem Cy., 22, GB3015, doi:10.1029/2007GB003101, 2008.

Moore, J., Doney, S., and Lindsay, K.: Upper ocean ecosystem dynamics and iron cycling in a global threedimensional model, Global Biogeochem Cy., 18, GB4028, doi:10.1029/2004GB002220, 2004.

Najjar, R. G., Jin, X., Louanchi, F., Aumont, O., Caldeira, K., Doney, S. C., Dutay, J.-C., Follows, M., Gruber, N., Joos, F., Lindsay, K., Maier-Reimer, E., Matear, R. J., Matsumoto, K., Monfray, P., Mouchet, A., Orr, J. C., Plattner, G.-K., Sarmiento, J. L., Schlitzer, R., Slater, R. D., Weirig, M.-F., Yamanaka, Y., and Yool, A.: Impact of circulation on export production, dissolved organic matter, and dissolved oxygen in the ocean: results from phase II of the Ocean Carbon-cycle Model Intercomparison Project (OCMIP-2), Global Biogeochem Cy., 21, GB3007, doi:10.1029/2006GB002857, 2007.

Nilsson, G. E., Dixson, D. L., Domenici, P., McCormick, M. I., Sørensen, C., Watson, S., and Munday, P. L.: Near-future carbon dioxide levels alter fish behaviour by interfering with neurotransmitter function, Nat. Clim. Change, 22, 5232-5250, 2012.

Orr, J., Fabry, V., Aumont, O., Bopp, L., Doney, S., Feely, R., Gnanadesikan, A., Gruber, N., Ishida, A., Joos, F., Key, R., Lindsay, K., Maier-Reimer, E., Matear, R., Monfray, P., Mouchet, A., Najjar, R., Plattner, G., Rodgers, K., Sabine, C., Sarmiento, J., Schlitzer, R., Slater, R., Totterdell, I., Weirig, M., Yamanaka, Y., and Yool, A.: Anthropogenic ocean acidification over the twentyfirst century and its impact on calcifying organisms, Nature, 437, 681-686, 2005.

Oschlies, A., Schulz, K. G., Riebesell, U., and Schmittner, A.: Simulated 21st century's increase in oceanic suboxia by $\mathrm{CO}_{2}$ enhanced biotic carbon export, Global Biogeochem Cy., 22, GB4008, doi:10.1029/2007GB003147, 2008.
Paulmier, A., Ruiz-Pino, D., and Garçon, V.: $\mathrm{CO}_{2}$ maximum in the oxygen minimum zone (OMZ), Biogeosciences, 8, 239-252, doi:10.5194/bg-8-239-2011, 2011.

Pfeil, B., Olsen, A., Bakker, D. C. E., Hankin, S., Koyuk, H., Kozyr, A., Malczyk, J., Manke, A., Metzl, N., Sabine, C. L., Akl, J., Alin, S. R., Bellerby, R. G. J., Borges, A., Boutin, J., Brown, P. J., Cai, W.-J., Chavez, F. P., Chen, A., Cosca, C., Fassbender, A. J., Feely, R. A., González-Dávila, M., Goyet, C., HardmanMountford, N., Heinze, C., Hood, M., Hoppema, M., Hunt, C. W., Hydes, D., Ishii, M., Johannessen, T., Jones, S. D., Key, R. M., K/'ortzinger, A., Landschützer, P., Lauvset, S. K., Lefèvre, N., Lenton, A., Lourantou, A., Merlivat, L., Midorikawa, T., Mintrop, L., Miyazaki, C., Murata, A., Nakadate, A., Nakano, Y., Nakaoka, S., Nojiri, Y., Omar, A. M., Padin, X. A., Park, G.-H., Paterson, K., Perez, F. F., Pierrot, D., Poisson, A., Ríos, A. F., Santana-Casiano, J. M., Salisbury, J., Sarma, V. V. S. S., Schlitzer, R., Schneider, B., Schuster, U., Sieger, R., Skjelvan, I., Steinhoff, T., Suzuki, T., Takahashi, T., Tedesco, K., Telszewski, M., Thomas, H., Tilbrook, B., Tjiputra, J., Vandemark, D., Veness, T., Wanninkhof, R., Watson, A. J., Weiss, R., Wong, C. S., and Yoshikawa-Inoue, H.: A uniform, quality controlled Surface Ocean $\mathrm{CO}_{2}$ Atlas (SOCAT), Earth Syst. Sci. Data Discuss., 5, 735-780, doi:10.5194/essdd-5-735-2012, 2012.

Plattner, G. K., Joos, F., Stocker, T. F., and Marchal, O.: Feedback mechanisms and sensitivities of ocean carbon uptake under global warming, Tellus B, 53, 564-592, 2001.

Plattner, G., Joos, F., and Stocker, T.: Revision of the global carbon budget due to changing air-sea oxygen fluxes, Global Biogeochem Cy., 16, 1096-1108, doi:10.1029/2001GB001746, 2002.

Pörtner, H. O. and Farrell, A. P.: Physiology and climate change, Science, 322, 690-692, doi:10.1126/science.1163156, 2008.

Pörtner, H. O., Langenbuch, M., and Michaelidis, B.: Synergistic effects of temperature extremes, hypoxia, and increases in $\mathrm{CO}_{2}$ on marine animals: from Earth history to global change, J. Geophys. Res., 110, C09S10, doi:10.1029/2004JC002561, 2004.

Pörtner, H. O., Bock, C., Knust, R., Lannig, G., Lucassen, M., Mark, F., and Sartoris, F.: Cod and climate in a latitudinal cline: physiological analyses of climate effects in marine fishes, Clim. Res., 37, 253-270, 2008.

Pörtner, H. O., Gutowska, M., Ishimats, A., Lucassen, M., Melzner, F., and Seibel, B.: Effects of ocean acidification on nektonic organisms, in: Ocean Acidification, edited by: Gattuso, J.P. and Hansson, L., Oxford University Press, Oxford, 154-175, 2011.

Redfield, A. C., Ketchum, H., and Richards, F. A.: The influence of organisms on the composition of seawater, in: The Sea, Wiley Interscience, New York, 2, 26-77, 1963.

Riebesell, U., Schulz, K. G., Bellerby, R. G. J., Botros, M., Fritsche, P., Meyerhofer, M., Neill, C., Nondal, G., Oschlies, A., Wohlers, J., and Zollner, E.: Enhanced biological carbon consumption in a high $\mathrm{CO}_{2}$ ocean, Nature, 450, 545-548, 2007.

Roeckner, E., Brokopf, R., Esch, M., Giorgetta, M., Hagemann, S., Kornblueh, L., Manzini, E., Schlese, U., and Schulzweida, U.: Sensitivity of simulated climate to horizontal and vertical resolution in the ECHAM5 atmosphere model, J. Climate, 19, 37713791, 2006.

Roy, T., Bopp, L., Gehlen, M., Schneider, B., Cadule, P., Frölicher, T. L., Segschneider, J., Tjiputra, J., Heinze, C., 
and Joos, F.: Regional impacts of climate change and atmospheric $\mathrm{CO}_{2}$ on future ocean carbon uptake: a multimodel linear feedback analysis, J. Climate, 24, 2300-2318, doi:10.1175/2010JCLI3787.1, 2011.

Sabine, C. L., Feely, R. A., Gruber, N., Key, R. M., Lee, K., Bullister, J. L., Wanninkhof, R., Wong, C. S., Wallace, D. W. R., Tilbrook, B., Millero, F. J., Peng, T.-H., Kozyr, A., Ono, T., and Rios, A. F.: The oceanic sink for anthropogenic $\mathrm{CO}_{2}$, Science, 305, 367-371, 2004.

Sarmiento, J. L. and Gruber, N.: Saturation concentration of gases in seawater, in: Ocean Biogeochemical Dynamics, Princeton University Press, Princeton, p. 81, 2006.

Sarmiento, J. L., Hughes, T. M. C., Stouffer, R. J., and Manabe, S.: Simulated response of the ocean carbon cycle to anthropogenic climate warming, Nature, 393, 245-249, 1998.

Schmittner, A., Oschlies, A., Matthews, H., and Galbraith, E.: Future changes in climate, ocean circulation, ecosystems, and biogeochemical cycling simulated for a business-as-usual $\mathrm{CO}_{2}$ emission scenario until year $4000 \mathrm{AD}$, Global Biogeochem Cy., 22, GB1013, doi:10.1029/2007GB002953, 2008.

Schneider, B., Bopp, L., Gehlen, M., Segschneider, J., Frölicher, T. L., Cadule, P., Friedlingstein, P., Doney, S. C., Behrenfeld, M. J., and Joos, F.: Climate-induced interannual variability of marine primary and export production in three global coupled climate carbon cycle models, Biogeosciences, 5, 597-614, doi:10.5194/bg-5-597-2008, 2008.

Seibel, B. A., Oschlies, A., and Childress, J. J.: The real limits to marine life: a further critique of the Respiration Index, Biogeosciences Discuss., 9, 16521-16532, 10.5194/bgd-9-16521-2012, 2012.

Six, K. and Maier-Reimer, E.: Effects of plankton dynamics on seasonal carbon fluxes in an ocean general circulation model, Global Biogeochem Cy., 10, 559-583, 1996.

Smith, R. and Gent, P.: The Parallel Ocean Program (POP) Reference Manual, Technical Report LAUR-02-2484, Tech. Rep., Los Alamos National Laboratory (LANL), USA, 2004.

Steinacher, M., Joos, F., Frölicher, T. L., Plattner, G.-K., and Doney, S. C.: Imminent ocean acidification in the Arctic projected with the NCAR global coupled carbon cycle-climate model, Biogeosciences, 6, 515-533, doi:10.5194/bg-6-5152009, 2009.

Steinacher, M., Joos, F., Frölicher, T. L., Bopp, L., Cadule, P., Cocco, V., Doney, S. C., Gehlen, M., Lindsay, K., Moore, J. K., Schneider, B., and Segschneider, J.: Projected 21st century decrease in marine productivity: a multi-model analysis, Biogeosciences, 7, 979-1005, doi:10.5194/bg-7-979-2010, 2010.

Stramma, L., Johnson, G. C., Sprintall, J., and Mohrholz, V.: Expanding oxygen-minimum zones in the tropical oceans, Science, 320, 655-658, doi:10.1126/science.1153847, 2008.
Stramma, L., Oschlies, A., and Schmidtko, S.: Anticorrelated observed and modeled trends in dissolved oceanic oxygen over the last 50 years, Biogeosciences Discuss., 9, 4595-4626, doi:10.5194/bgd-9-4595-2012, 2012.

Takahashi, T., Broeker, W., and Langer, S.: Redfield ratio based on chemical data from isopycnal surfaces, J. Geophys. Res.-Oceans, 90, 6907-6924, 1985.

Takatani, Y., Sasano, D., Nakano, T., Midorikawa, T., and Ishii, M.: Decrease of dissolved oxygen after the mid-1980s in the western North Pacific subtropical gyre along the $137^{\circ}$ E repeat section, Global Biogeochem Cy., 26, GB2013, doi:10.1029/2011GB004227, 2012.

Taylor, K. E.: Summarizing multiple aspects of model performance in a single diagram, J. Geophys. Res., 106, 7183-7192, 2001.

Thomas, H., Prowe, A. E. F., Lima, I. D., Doney, S. C., Wanninkhof, R., Greatbatch, R. J., Schuster, U., and Corbiere, A.: Changes in the North Atlantic Oscillation influence $\mathrm{CO}_{2}$ uptake in the North Atlantic over the past 2 decades, Global Biogeochem Cy., 22, GB4027, doi:10.1029/2007GB003167, 2008.

Tjiputra, J. F., Assmann, K., Bentsen, M., Bethke, I., Otterå, O. H., Sturm, C., and Heinze, C.: Bergen Earth system model (BCM-C): model description and regional climate-carbon cycle feedbacks assessment, Geosci. Model Dev., 3, 123-141, doi:10.5194/gmd-3-123-2010, 2010.

Tjiputra, J. F., Olsen, A., Assmann, K., Pfeil, B., and Heinze, C.: A model study of the seasonal and long-term North Atlantic surface $p \mathrm{CO}_{2}$ variability, Biogeosciences, 9, 907-923, doi:10.5194/bg9-907-2012, 2012.

Watson, A. J., Schuster, U., Bakker, D. C. E., Bates, N. R., Corbiere, A., Gonzalez-Davila, M., Friedrich, T., Hauck, J., Heinze, C., Johannessen, T., Koertzinger, A., Metzl, N., Olafsson, J., Olsen, A., Oschlies, A., Antonio Padin, X., Pfeil, B., Magdalena Santana-Casiano, J., Steinhoff, T., Telszewski, M., Rios, A. F., Wallace, D. W. R., and Wanninkhof, R.: Tracking the variable North Atlantic sink for atmospheric $\mathrm{CO}_{2}$, Science, 326, 1391-1393, 2009.

Weaver, A. J., Eby, M., and Wiebe, E. C.: The UVic Earth system climate model: model description, climatology, and applications to past, present and future climates, Atmos. Ocean, 39, 361-428, 2001.

Whitney, F. A., Freeland, H. J., and Robert, M.: Persistently declining oxygen levels in the interior waters of the eastern subarctic Pacific, Global Biogeochem. Cy., 75, 179-199, doi:10.1016/j.pocean.2007.08.007, 2007.

Yeager, S., Shields, C., Large, W., and Hack, J.: The low-resolution CCSM3, J. Climate, 19, 2545-2566, 2006. 